SANDIA REPORT

SAND2007-8012

Unlimited Release

Printed December 2007

\title{
Initial Case for Splitting Carbon Dioxide to Carbon Monoxide and Oxygen
}

James E. Miller

Prepared by

Sandia National Laboratories

Albuquerque, New Mexico 87185 and Livermore, California 94550

Sandia is a multiprogram laboratory operated by Sandia Corporation,

a Lockheed Martin Company, for the United States Department of Energy's

National Nuclear Security Administration under Contract DE-AC04-94AL85000.

Approved for public release; further dissemination unlimited. 
Issued by Sandia National Laboratories, operated for the United States Department of Energy by Sandia Corporation.

NOTICE: This report was prepared as an account of work sponsored by an agency of the United States Government. Neither the United States Government, nor any agency thereof, nor any of their employees, nor any of their contractors, subcontractors, or their employees, make any warranty, express or implied, or assume any legal liability or responsibility for the accuracy, completeness, or usefulness of any information, apparatus, product, or process disclosed, or represent that its use would not infringe privately owned rights. Reference herein to any specific commercial product, process, or service by trade name, trademark, manufacturer, or otherwise, does not necessarily constitute or imply its endorsement, recommendation, or favoring by the United States Government, any agency thereof, or any of their contractors or subcontractors. The views and opinions expressed herein do not necessarily state or reflect those of the United States Government, any agency thereof, or any of their contractors.

Printed in the United States of America. This report has been reproduced directly from the best available copy.

Available to DOE and DOE contractors from

U.S. Department of Energy

Office of Scientific and Technical Information

P.O. Box 62

Oak Ridge, TN 37831

Telephone: $\quad$ (865) 576-8401

Facsimile: (865) 576-5728

E-Mail: reports@adonis.osti.gov

Online ordering: http://www.osti.gov/bridge

Available to the public from

U.S. Department of Commerce

National Technical Information Service

5285 Port Royal Rd.

Springfield, VA 22161

Telephone: $\quad$ (800) 553-6847

Facsimile: (703) 605-6900

E-Mail: $\quad$ orders@ntis.fedworld.gov

Online order: $\quad$ http://www.ntis.gov/help/ordermethods.asp?loc=7-4-0\#online

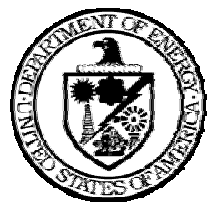


SAND2007-8012

Unlimited Release

Printed December 2007

\title{
Initial Case for Splitting Carbon Dioxide to Carbon Monoxide and Oxygen
}

\author{
James E. Miller \\ Sandia National Laboratories \\ P.O. Box 5800 \\ Albuquerque, NM 87185-1349
}

\begin{abstract}
The United States presently imports almost $2 / 3$ of the more than 20 million barrels of petroleum that it consumes daily. The largest fraction of this consumption, again about $2 / 3$, is for transportation. Unfortunately, much of the non-domestic oil extraction, which we both directly and indirectly rely on, is from fields in unstable parts of the world. The national security and economic implications of our dependence upon foreign oil as well as the dangers of climate change resulting from green house gas emissions prompts a search for alternative sources of liquid fuels. Independence from problematic oil producers can be achieved to a great degree by applying decades-old synfuel technologies to convert non-conventional resources such as coal, oil-shale and tar-sands into liquid fuels. Unfortunately tapping into and converting these resources into liquid fuels only exacerbates green house gas emissions as they are carbon rich, but hydrogen deficient. Additionally, deploying these technologies requires large investments in time and capital.

The "hydrogen economy" is a newer alternative, but it poses significant infrastructure and technological challenges. However, if we adopt revolutionary thinking about energy and fuels, it may be possible to the meet the future fuel challenges while maintaining our traditional hydrocarbon fuel framework. We must recognize that hydrocarbon fuels are energy carriers, not energy sources. The energy stored in a hydrocarbon is released for utilization by oxidation to form $\mathrm{CO}_{2}$ and $\mathrm{H}_{2} \mathrm{O}$. Furthermore, just as $\mathrm{H}_{2} \mathrm{O}$ can be "reenergized" by applying energy to split water back into $\mathrm{H}_{2}$ and $\mathrm{O}_{2}$, hydrocarbons can be recycled by capturing $\mathrm{CO}_{2}$ (and $\mathrm{H}_{2} \mathrm{O}$ ) and "re-energizing" them back into hydrocarbon form. That is, there is a hydrocarbon analogy to the envisioned hydrogen economy that realizes the benefits of hydrogen while capitalizing on much of the existing liquid fuel infrastructure. Of course, the only credible pathway for implementing this vision is through the application of persistent energy sources (e.g. solar or nuclear). In this document, the concept of applying high temperature thermochemical cycles to split $\mathrm{CO}_{2}$ into $\mathrm{CO}$ and $\mathrm{O}_{2}$ as a starting point for synthetic fuel production is introduced and potential advantages of this approach are discussed.
\end{abstract}




\section{Table of Contents}

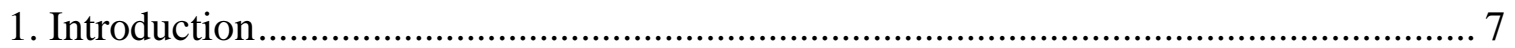

2. Underlying Assumptions ..................................................................................... 7

3. Thermodynamics of Water and Carbon Dioxide Splitting and the Water Gas Shift (WGS) Reaction ...................................................................................................... 8

4. Thermodynamics of Methanol Synthesis.................................................................. 11

5. Reaction Rates for Methanol Synthesis ....................................................................... 14

6. Thermodynamics of Dimethyl Ether (DME) Synthesis................................................. 18

7. Additional Thermodynamic Considerations ……………………………………..... 21

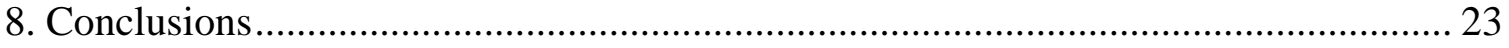

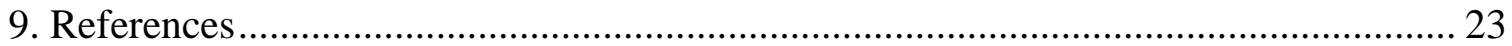

Appendix A. Reactor Modeling (Bussche and Froment)................................................. 25

Appendix B. Reactor Modeling (Kubota et al.)............................................................ 27

\section{List of Figures}

Figure 1. Free energy change for the reactions $\mathrm{H}_{2} \mathrm{O} \rightarrow \mathrm{H}_{2}+1 / 2 \mathrm{O}_{2}$ and $\mathrm{CO}_{2} \rightarrow \mathrm{CO}+1 / 2$ $\mathrm{O}_{2}$. Calculations performed using HSC Chemistry for Windows software.

Figure 2. Free energy changes for ceria-based thermochemical water and $\mathrm{CO}_{2}$ splitting. Reactions are $\mathrm{CeO}_{2} \rightarrow 1 / 2 \mathrm{Ce}_{2} \mathrm{O}_{3}+1 / 4 \mathrm{O}_{2} ; \mathrm{Ce}_{2} \mathrm{O}_{3}+\mathrm{H}_{2} \mathrm{O} \rightarrow 2 \mathrm{CeO}_{2}+\mathrm{H}_{2}$; and $\mathrm{Ce}_{2} \mathrm{O}_{3}+\mathrm{CO}_{2}$ $\rightarrow 2 \mathrm{CeO}_{2}+\mathrm{CO}$. Calculations performed using HSC Chemistry for Windows software. 9

Figure 3. Thermodynamic equilibrium composition as a function of temperature for the WGS reaction $\mathrm{CO}+\mathrm{H}_{2} \mathrm{O}(\mathrm{g})=\mathrm{CO}_{2}+\mathrm{H}_{2}$. Note that equilibrium is practically independent of pressure.

Figure 4. Thermodynamic equilibrium compositions as a function of temperature for the WGS reaction $\mathrm{CO}+\mathrm{H}_{2} \mathrm{O}(\mathrm{g})=\mathrm{CO}_{2}+\mathrm{H}_{2}$. A) Feed is $3: 1 \mathrm{H}_{2}: \mathrm{CO}_{2}$. B) Feed is $2: 3$

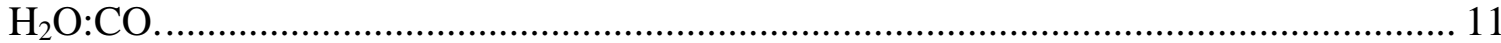

Figure 5. Thermodynamic equilibrium composition as a function of temperature for the

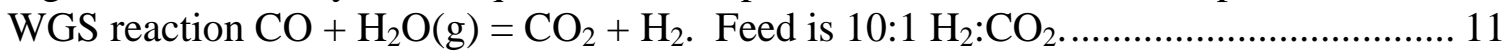

Figure 6. Thermodynamic equilibria for methanol synthesis from syngas $2 \mathrm{H}_{2}+\mathrm{CO}=$

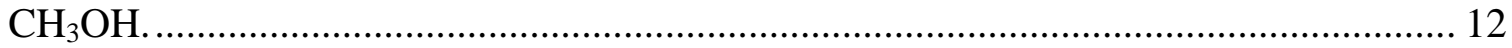

Figure 7. Thermodynamic equilibria for methanol synthesis from $\mathrm{H}_{2}$ and $\mathrm{CO}_{2} . \quad 3 \mathrm{H}_{2}+$

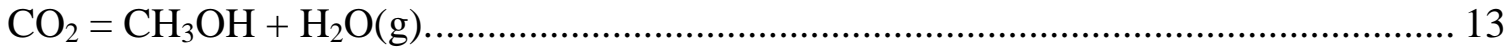

Figure 8. Thermodynamic equilibria for methanol synthesis from $\mathrm{H}_{2} \mathrm{O}$ and $\mathrm{CO}$.

$2 \mathrm{H}_{2} \mathrm{O}(\mathrm{g})+3 \mathrm{CO}=\mathrm{CH}_{3} \mathrm{OH}+2 \mathrm{CO}_{2}$

Figure 9. Calculated conversion of $\mathrm{CO}_{2}$-containing synthesis gas to methanol over $\mathrm{Cu} / \mathrm{ZnO} / \mathrm{Al}_{2} \mathrm{O}_{3}$ 
Figure 10. Calculated conversion of synthesis gas to methanol over $\mathrm{Cu} / \mathrm{ZnO} / \mathrm{Al}_{2} \mathrm{O}_{3}$.

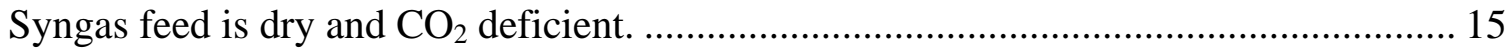

Figure 11. Calculated conversion of synthesis gas to methanol over $\mathrm{Cu} / \mathrm{ZnO} / \mathrm{Al}_{2} \mathrm{O}_{3}$.

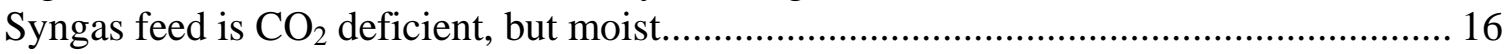

Figure 12. Calculated conversion of dry $3: 1 \mathrm{H}_{2}: \mathrm{CO}_{2}$ mixture to methanol over

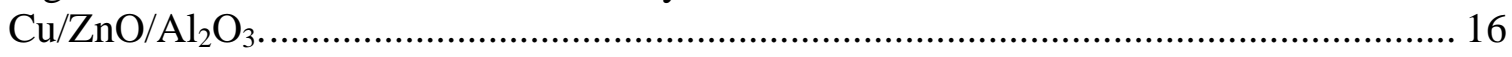

Figure 13. Calculated conversion of dry $3: 1 \mathrm{H}_{2}: \mathrm{CO}_{2}$ mixture to methanol over $\mathrm{Cu} / \mathrm{ZnO} / \mathrm{Al}_{2} \mathrm{O}_{3}$. Reactor (or residence time) has been lengthened by a factor of 4 to further illustrate sluggish kinetics.

Figure 14. Calculated conversion of 3:2 CO: $\mathrm{H}_{2} \mathrm{O}$ mixture to methanol over $\mathrm{Cu} / \mathrm{ZnO} / \mathrm{Al}_{2} \mathrm{O}_{3}$.

Figure 15. Thermodynamic equilibria as a function of temperature for methanol dehydration to DME $\left(2 \mathrm{CH}_{3} \mathrm{OH} \leftrightarrow \mathrm{CH}_{3} \mathrm{OCH}_{3}+\mathrm{H}_{2} \mathrm{O}\right)$. Pressure has little effect on the equilibrium.

Figure 16. Thermodynamic equilibria as a function of temperature and pressure for DME synthesis from syngas with water as a co-product $\left(2 \mathrm{CO}+4 \mathrm{H}_{2} \leftrightarrow \mathrm{CH}_{3} \mathrm{OCH}_{3}+\mathrm{H}_{2} \mathrm{O}\right) \ldots 19$

Figure 17. Thermodynamic equilibria as a function of temperature and pressure for DME synthesis from syngas with carbon dioxide as a co-product $\left(3 \mathrm{CO}+3 \mathrm{H}_{2} \leftrightarrow \mathrm{CH}_{3} \mathrm{OCH}_{3}+\right.$

$\left.\mathrm{CO}_{2}\right)$ 20

Figure 18. Thermodynamic equilibria as a function of temperature and pressure for DME synthesis from a 3:1 mixture of $\mathrm{H}_{2}$ and $\mathrm{CO}_{2}\left(2 \mathrm{CO}_{2}+6 \mathrm{H}_{2} \leftrightarrow \mathrm{CH}_{3} \mathrm{OCH}_{3}+3 \mathrm{H}_{2} \mathrm{O}\right)$....... 20

Figure 19. Thermodynamic equilibria as a function of temperature and pressure for DME synthesis from a 2:1 mixture of $\mathrm{CO}$ and $\mathrm{H}_{2} \mathrm{O}\left(6 \mathrm{CO}+3 \mathrm{H}_{2} \mathrm{O} \leftrightarrow \mathrm{CH}_{3} \mathrm{OCH}_{3}+4 \mathrm{CO}_{2}\right) \ldots \ldots . .21$

Figure B1. Calculated conversion of $\mathrm{CO}_{2}$-containing synthesis gas to methanol over $\mathrm{Cu} / \mathrm{ZnO} / \mathrm{Al}_{2} \mathrm{O}_{3}$ (Kubota Model).

Figure B2. Calculated conversion of synthesis gas to methanol over $\mathrm{Cu} / \mathrm{ZnO} / \mathrm{Al}_{2} \mathrm{O}_{3}$.

Syngas feed is dry and $\mathrm{CO}_{2}$ deficient (Kubota Model).

Figure B3. Calculated conversion of synthesis gas to methanol over $\mathrm{Cu} / \mathrm{ZnO} / \mathrm{Al}_{2} \mathrm{O}_{3}$. Syngas feed is $\mathrm{CO}_{2}$ deficient, but moist (Kubota Model).

Figure B4. Calculated conversion of dry $3: 1 \mathrm{H}_{2}: \mathrm{CO}_{2}$ mixture to methanol over $\mathrm{Cu} / \mathrm{ZnO} / \mathrm{Al}_{2} \mathrm{O}_{3}$ (Kubota Model).

Figure B5. Calculated conversion of 3:2 CO: $\mathrm{H}_{2} \mathrm{O}$ mixture to methanol over $\mathrm{Cu} / \mathrm{ZnO} / \mathrm{Al}_{2} \mathrm{O}_{3}$ (Kubota Model).

\section{List of Tables}

Table 1. Thermodynamics of reactions relevant to methanol and DME synthesis. 22 


\section{Introduction}

The United States presently imports almost $2 / 3$ of the more than 20 million barrels of petroleum that it consumes daily. The largest fraction of this consumption, again about $2 / 3$, is for transportation. Unfortunately, much of the non-domestic oil extraction, which we both directly and indirectly rely on, is from fields in unstable parts of the world. Thus, developing an independent, domestic source of transportation fuel is essential for the future security and economic well-being of the US. Additionally, the effect of unmitigated $\mathrm{CO}_{2}$ releases on the global climate is a growing concern both here and abroad. Independence from problematic oil producers can be achieved to a great degree through the utilization of non-conventional hydrocarbon resources such as coal, oil-shale and tar-sands. However, tapping into and converting these resources into liquid fuels only exacerbates green house gas (GHG) emissions as they are carbon rich, but hydrogen deficient. Solving this conundrum within the traditional hydrocarbon fuel framework requires us to adopt revolutionary thinking about energy and fuels. We must recognize that hydrocarbon fuels are energy carriers, not energy sources. The energy stored in a hydrocarbon is released for utilization by oxidation to form $\mathrm{CO}_{2}$ and $\mathrm{H}_{2} \mathrm{O}$. However, just as $\mathrm{H}_{2} \mathrm{O}$ can be "re-energized" by applying energy to split water back into $\mathrm{H}_{2}$ and $\mathrm{O}_{2}$, hydrocarbons can be recycled by capturing $\mathrm{CO}_{2}\left(\right.$ and $\left.\mathrm{H}_{2} \mathrm{O}\right)$ and "re-energizing" them back into hydrocarbon form. That is, there is a hydrocarbon analogy to the envisioned hydrogen economy. Of course, the only credible pathway for implementing this vision is through the application of persistent energy sources (e.g. solar or nuclear).

The most general way to convert $\mathrm{CO}_{2}$ and $\mathrm{H}_{2} \mathrm{O}$ into a fuel is through the intermediate production of synthesis gas or "syngas". Syngas is roughly a 1:2 mixture of $\mathrm{CO}$ and $\mathrm{H}_{2}$ whose exothermic conversion to fuel and other products is currently commercially practiced. Stated concisely, one key route to converting $\mathrm{CO}_{2}$ and $\mathrm{H}_{2} \mathrm{O}$ into fuel is the following "reenergizing" reaction:

$$
2 \mathrm{CO}_{2}+4 \mathrm{H}_{2} \mathrm{O} \rightarrow 2 \mathrm{CO}+4 \mathrm{H}_{2}+3 \mathrm{O}_{2}
$$

This reaction may of course be carried out either as written, or stepwise. For example, water splitting (WS) can be coupled with the reverse water gas shift reaction (RWGS) to produce syngas (Scheme 1).

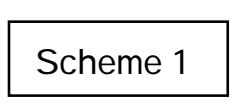

$$
\begin{gathered}
6 \mathrm{H}_{2} \mathrm{O} \rightarrow 6 \mathrm{H}_{2}+3 \mathrm{O}_{2} \\
\underline{2 \mathrm{CO}_{2}}+2 \mathrm{H}_{2} \rightarrow 2 \mathrm{CO}+2 \mathrm{H}_{2} \underline{O} \\
2 \mathrm{CO}_{2}+4 \mathrm{H}_{2} \mathrm{O} \rightarrow 2 \mathrm{CO}+4 \mathrm{H}_{2}+3 \mathrm{O}_{2}
\end{gathered}
$$

Recently, we proposed that it would be beneficial to split carbon dioxide and couple that reaction with the well known water gas shift reaction (WGS) to achieve the same result.

$$
\text { Scheme } 2
$$$$
6 \mathrm{CO}_{2} \rightarrow 6 \mathrm{CO}+3 \mathrm{O}_{2}
$$

$$
\begin{gathered}
\underline{4 \mathrm{CO}+4 \mathrm{H}_{2} \mathrm{O} \rightarrow 4 \mathrm{CO}_{2}} \underline{+4 \mathrm{H}_{2}} \\
2 \mathrm{CO}_{2}+4 \mathrm{H}_{2} \mathrm{O} \rightarrow 2 \mathrm{CO}+4 \mathrm{H}_{2}+3 \mathrm{O}_{2}
\end{gathered}
$$

Herein, we begin to document and expand on the case for splitting carbon dioxide into $\mathrm{CO}$ and $\mathrm{O}_{2}$ as an attractive alternative to water splitting.

\section{Underlying Assumptions}

In making the case for carbon dioxide splitting (CDS), we necessarily begin with several assumptions. First, we assume that the hydrogen economy makes sense. That is, most of 
the assumptions that underlie the case for the hydrogen economy are necessarily incorporated here. These include assumptions regarding the desirability of increasing domestic sources of fuel and decreasing greenhouse emissions, as well as the assumption that the application of renewable/sustainable resources to fuel production, as opposed to production of electricity, is appropriate. Going further, for the purposes of this document, we assume that liquid fuels provide significant advantages over hydrogen such as compatibility with the current infrastructure. That is, the discussion herein is primarily limited to a comparison of water splitting and carbon dioxide splitting as the key steps in fuel production from $\mathrm{CO}_{2}$ and water. The specific focus is on thermochemical processes as thermochemical water splitting is the most energy efficient approach to sustainable hydrogen production. The case for a $\mathrm{CO}_{2}$ economy over a $\mathrm{H}_{2}$ economy, or as an extension of the $\mathrm{H}_{2}$ economy, remains to be made in detail elsewhere.

\section{Thermodynamics of Water and Carbon Dioxide Splitting and the Water Gas Shift (WGS) Reaction}

Carbon dioxide and water are extraordinarily stable molecules. As shown in Figure 1, thermodynamics does not favor their decomposition, even at $3000{ }^{\circ} \mathrm{C}$. In addition to very high temperatures required, direct thermolysis is also made difficult in a practical sense by the inherent spatial coupling of the evolution of the different reaction products $\left(\mathrm{H}_{2}\right.$ and $\mathrm{O}_{2}$, or $\mathrm{CO}$ and $\mathrm{O}_{2}$ ). This coupling raises the possibility of recombination (possibly violent) and requires that difficult separations be performed.

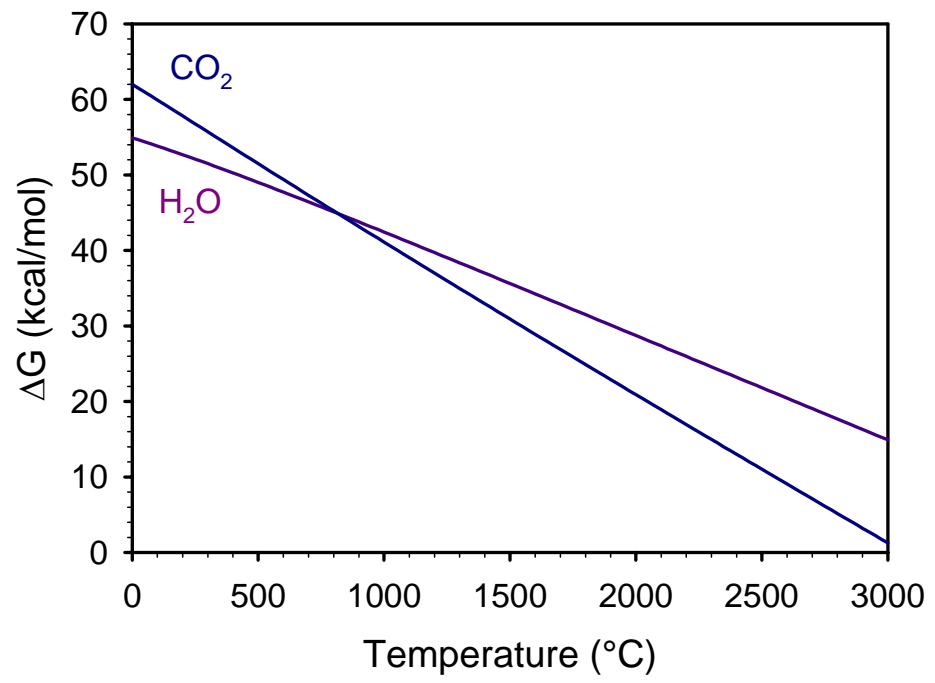

Figure 1. Free energy change for the reactions $\mathrm{H}_{2} \mathrm{O} \rightarrow \mathrm{H}_{2}+1 / 2 \mathrm{O}_{2}$ and $\mathrm{CO}_{2} \rightarrow \mathrm{CO}+1 / 2 \mathrm{O}_{2}$. Calculations performed using HSC Chemistry for Windows software.

An interesting feature of the thermolysis reactions is that at temperatures above about 800 ${ }^{\circ} \mathrm{C}, \mathrm{CO}_{2}$ is less stable than $\mathrm{H}_{2} \mathrm{O}$, while at lower temperatures it is more stable. This fact has interesting consequences and implications that are the main topic of this paper.

Figure 2 compares the thermodynamics of water and $\mathrm{CO}_{2}$ splitting assuming a $\mathrm{CeO}_{2}$ based thermochemical cycle. Calculations indicate that $\mathrm{CeO}_{2}$ spontaneously reduces (i.e. $\Delta \mathrm{G}$ is negative) to $\mathrm{Ce}_{2} \mathrm{O}_{3}$ at temperatures above about $2350{ }^{\circ} \mathrm{C}$. Note that while below 
the reported melting point of $\mathrm{CeO}_{2}\left(2600{ }^{\circ} \mathrm{C}\right)$ this temperature is above the melting point of the product $\mathrm{Ce}_{2} \mathrm{O}_{3}\left(2230^{\circ} \mathrm{C}\right)$. . In practice, partial reduction of ceria to various suboxides is reported to be possible at lower temperatures. In addition, the literature suggests that reduction temperatures can be lowered by alloying the ceria with other oxides, e.g. $\mathrm{ZrO}_{2}$. Certainly this is the case for chemical reduction with hydrogen. More interestingly, Figure 2 indicates that at any temperature below about $1500{ }^{\circ} \mathrm{C}$, reduction of $\mathrm{CO}_{2}$ to $\mathrm{CO}$ by $\mathrm{Ce}_{2} \mathrm{O}_{3}$ is thermodynamically favored, and furthermore, at temperatures greater than $800{ }^{\circ} \mathrm{C}, \mathrm{CO}_{2}$ reduction is more favored than water reduction. ${ }^{\dagger}$ This raises the possibility that $\mathrm{CO}_{2}$ splitting can be accomplished with higher conversions (more negative $\Delta \mathrm{G}$ ) and higher reaction rates (at higher temperatures) than thermochemical water splitting.

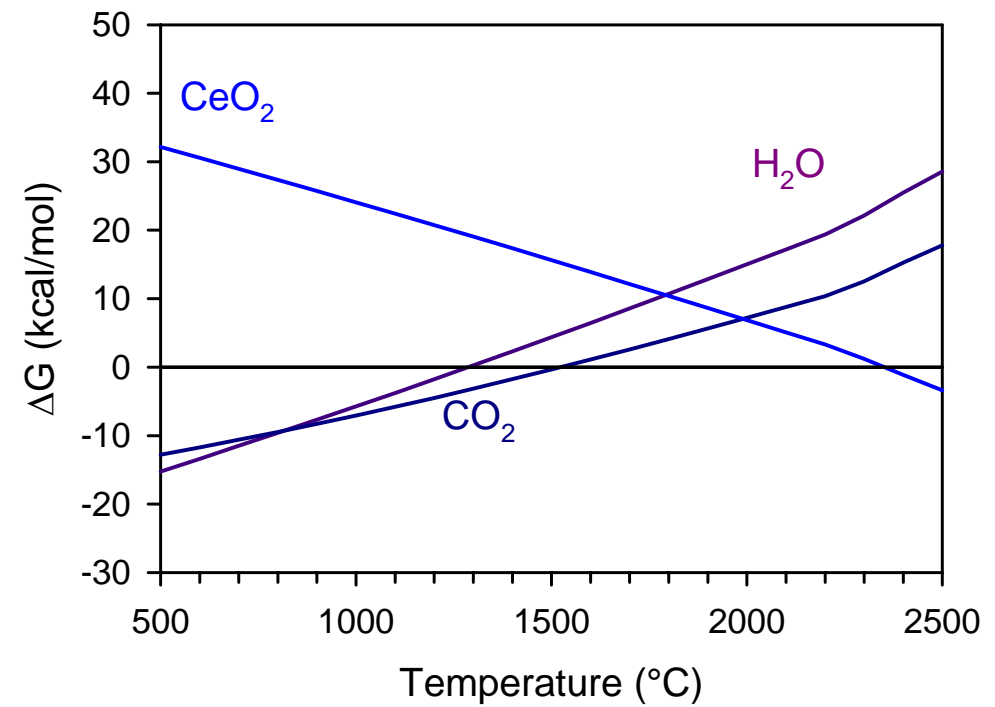

Figure 2. Free energy changes for ceria-based thermochemical water and $\mathrm{CO}_{2}$ splitting. Reactions are $\mathrm{CeO}_{2} \rightarrow 1 / 2 \mathrm{Ce}_{2} \mathrm{O}_{3}+1 / 4 \mathrm{O}_{2} ; \mathrm{Ce}_{2} \mathrm{O}_{3}+\mathrm{H}_{2} \mathrm{O} \rightarrow 2 \mathrm{CeO}_{2}+\mathrm{H}_{2}$; and $\mathrm{Ce}_{2} \mathrm{O}_{3}+\mathrm{CO}_{2} \rightarrow 2 \mathrm{CeO}_{2}+\mathrm{CO}$. Calculations performed using HSC Chemistry for Windows software.

Figure 3 illustrates a second key point resulting from the thermodynamics and in particular the crossover in the free energy that occurs at $800{ }^{\circ} \mathrm{C}$. While $\mathrm{CO}_{2}$ is less stable than water at temperatures $>800{ }^{\circ} \mathrm{C}$, it is more stable than water at temperatures $<800$ ${ }^{\circ} \mathrm{C}$. Therefore, at temperatures $<800{ }^{\circ} \mathrm{C}$, WGS favors the production of $\mathrm{CO}_{2}$ and $\mathrm{H}_{2}$. That is, $\mathrm{H}_{2}$ can readily be produced through low-temperature WGS of CO with steam. Conversely, $\mathrm{CO}$ can not readily be produced by reacting $\mathrm{H}_{2}$ with $\mathrm{CO}_{2}$. Figure 3 shows

\footnotetext{
* The reduction of $\mathrm{CeO}_{2}$ is calculated to occur at a lower temperature than that of $\mathrm{Fe}_{3} \mathrm{O}_{4}$ for which $\Delta \mathrm{G}$ is negative for temperatures $>2830^{\circ} \mathrm{C}$. Furthermore, the melting points of the cerium oxides are higher than that of the Fe oxides $\left(1538{ }^{\circ} \mathrm{C}\right.$ for $\mathrm{Fe}_{3} \mathrm{O}_{4}$ and $1370{ }^{\circ} \mathrm{C}$ for $\mathrm{FeO}$ ). Nonetheless we (and others) have been able to achieve good results for water splitting by thermally reducing Co-doped $\mathrm{Fe}_{3} \mathrm{O}_{4}$ mixed with $\mathrm{ZrO}_{2}$ at $1400^{\circ} \mathrm{C}$.

${ }^{\dagger}$ Currently we are reducing an excess of water at $1100^{\circ} \mathrm{C}$ over a cobalt-doped ferrite. Calculations in HSC for the reaction of steam with $\mathrm{FeO}$ indicate that $\Delta \mathrm{G}$ for the reaction is still positive at this temperature. However, at lower temperatures, the kinetics of the reaction are exceptionally slow. The calculations suggest that the combination of ceria and $\mathrm{CO}_{2}$ (or even steam) will result in higher conversions with improved kinetics (more negative $\Delta \mathrm{G}$ at higher temperatures).
} 
that even very high temperatures do not drive the equilibrium completely towards $\mathrm{CO}$ and $\mathrm{H}_{2} \mathrm{O}$.

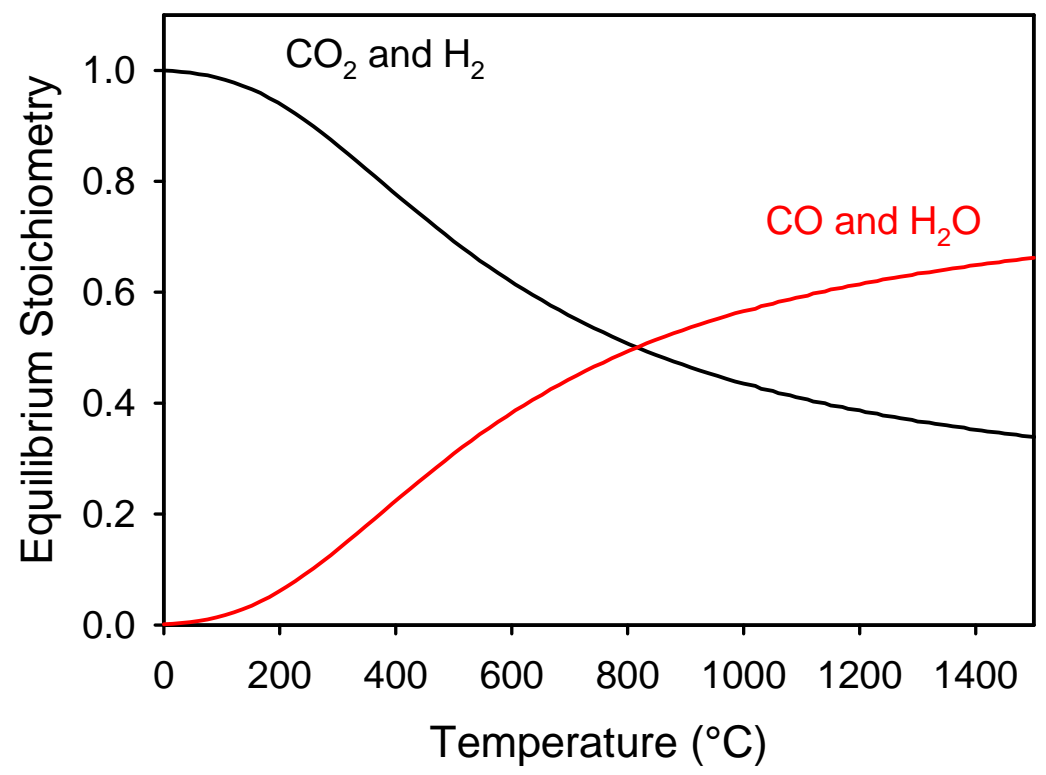

Figure 3. Thermodynamic equilibrium composition as a function of temperature for the WGS reaction $\mathrm{CO}+\mathrm{H}_{2} \mathrm{O}(\mathrm{g})=\mathrm{CO}_{2}+\mathrm{H}_{2}$. Note that equilibrium is practically independent of pressure.

The implications of this result are significant. First, it suggests that $\mathrm{CO}_{2}$ should be considered as a working fluid for thermochemical hydrogen production cycles. In this case one must compare the cost of evaporating, heating, circulating, cooling and condensing excess steam to the cost of operating a WGS reactor and recovering $\mathrm{CO}_{2}$ from $\mathrm{H}_{2}$ for recycle. Operability issues for the two fluids should also be compared. For example, steam is known to promote the volatilization of metal oxides.

The second implication of this result pertains to the production of hydrocarbon fuels via a syngas intermediate. Figure 4A illustrates the WGS equilibrium for the stoichiometry 3:1 $\mathrm{H}_{2}: \mathrm{CO}_{2}$, the basic stoichiometry to produce a syngas product with $2: 1 \mathrm{H}_{2}$ :CO stoichiometry from $\mathrm{H}_{2}$ and $\mathrm{CO}_{2}$. The figure shows that the 2:1 stoichiometry is never realized for this gas mixture, even at a temperature of $900{ }^{\circ} \mathrm{C}$. However, the temperature for $50 \%$ conversion of $\mathrm{CO}_{2}$ to $\mathrm{CO}$ has shifted from $818{ }^{\circ} \mathrm{C}$ for the $1: 1$ mixture (Figure 3) to ca. $500{ }^{\circ} \mathrm{C}$ for the $3: 1$ mixture. Figure 5 illustrates the impact of using an even greater excess of $\mathrm{H}_{2}$ in the feed relative to $\mathrm{CO}_{2}$. For a $10: 1$ feed, $50 \%$ of the $\mathrm{CO}_{2}$ is converted to CO at ca. $355^{\circ} \mathrm{C}$.

In contrast to the results for $\mathrm{H}_{2}$ and $\mathrm{CO}_{2}$, mixtures of $\mathrm{CO}$ and $\mathrm{H}_{2} \mathrm{O}$ are quite capable of yielding 2:1 $\mathrm{H}_{2}$ :CO ratios. Figure 4B illustrates the WGS equilibrium for the stoichiometry 2:3 $\mathrm{H}_{2} \mathrm{O}: \mathrm{CO}$, the basic ratio required to produce a $2: 1 \mathrm{H}_{2}$ : $\mathrm{CO}$ product. In this case, the equilibrium $\mathrm{H}_{2}$ : $\mathrm{CO}$ ratio ranges from 2 at $100{ }^{\circ} \mathrm{C}$ to 1.8 at $300{ }^{\circ} \mathrm{C}$. That is, at any temperature $<300{ }^{\circ} \mathrm{C}$, the equilibrium conversion of $\mathrm{H}_{2} \mathrm{O}$ to $\mathrm{H}_{2}$ is $>95 \%$. 

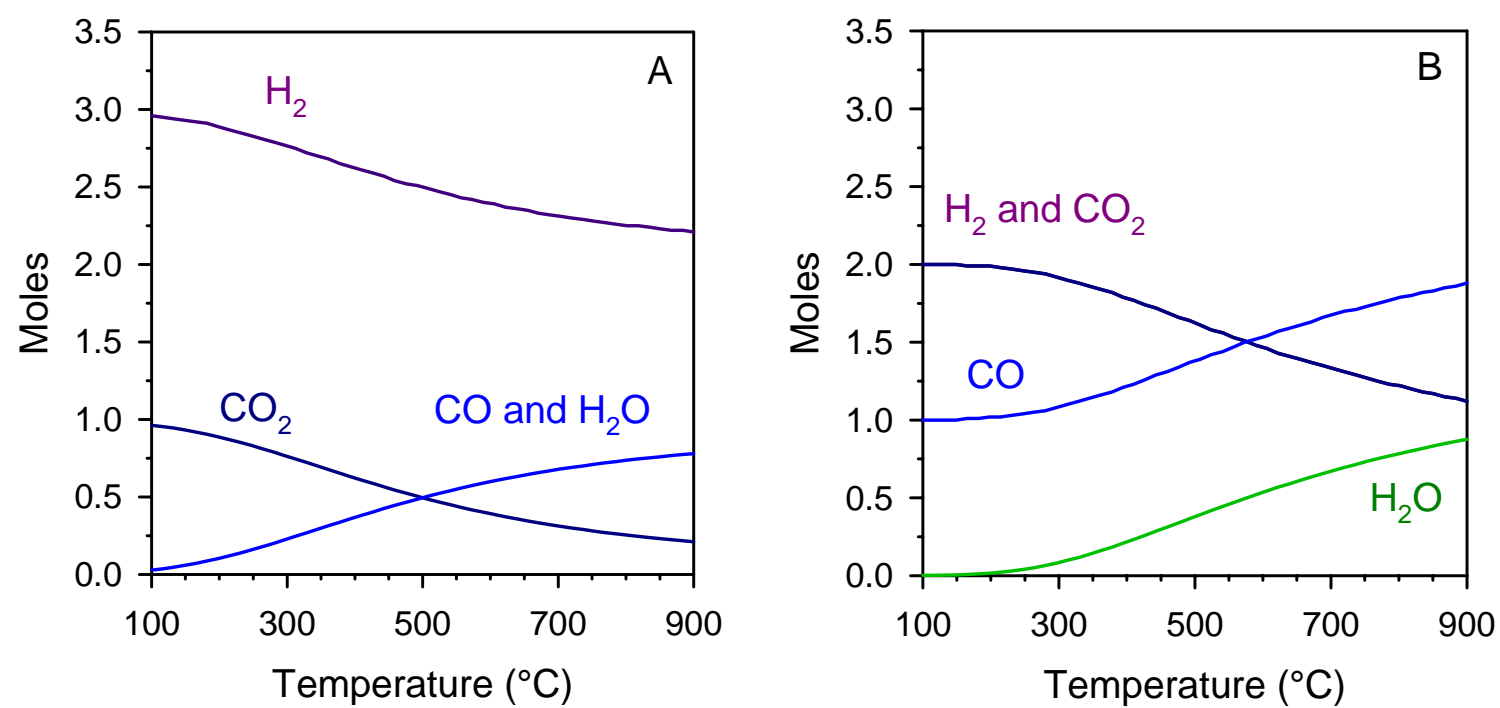

Figure 4. Thermodynamic equilibrium compositions as a function of temperature for the WGS reaction $\mathrm{CO}+\mathrm{H}_{2} \mathrm{O}(\mathrm{g})=\mathrm{CO}_{2}+\mathrm{H}_{2}$. A) Feed is 3:1 $\mathrm{H}_{2}: \mathrm{CO}_{2}$. B) Feed is 2:3 $\mathrm{H}_{2} \mathrm{O}: \mathrm{CO}$.

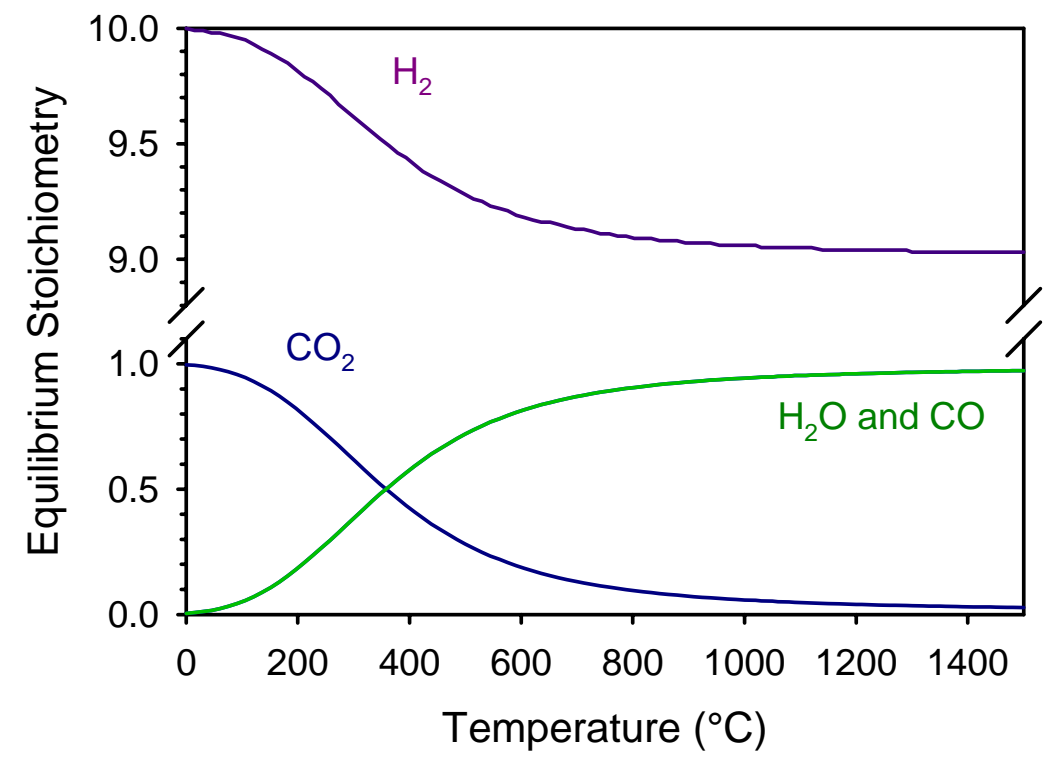

Figure 5. Thermodynamic equilibrium composition as a function of temperature for the WGS reaction $\mathrm{CO}$ $+\mathrm{H}_{2} \mathrm{O}(\mathrm{g})=\mathrm{CO}_{2}+\mathrm{H}_{2}$. Feed is $10: 1 \mathrm{H}_{2}: \mathrm{CO}_{2}$.

\section{Thermodynamics of Methanol Synthesis}

The discussion above comparing WGS and RWGS chemistry is in some ways based on an oversimplification. In truth, there is not necessarily a requirement to perform a WGS or RWGS reaction to produce syngas in a separate step prior to producing a hydrocarbon product. That is, although WGS can be and is performed as a separate step, the WGS chemistry is also typically promoted by syngas-to-hydrocarbon catalysts. Additionally, if necessary, a catalyst bed of mixed functionalities is conceivable. Therefore, mixtures of 
$\mathrm{H}_{2}$ and $\mathrm{CO}_{2}$ or mixtures of $\mathrm{CO}$ and steam can likely be more directly converted to a hydrocarbon product than perhaps implied by the earlier text.

Consider the example of methanol $\left(\mathrm{CH}_{3} \mathrm{OH}\right)$. Methanol can be selectively produced from syngas in high yields and despite many shortcomings as a fuel, has recently been touted as an alternate to hydrogen [1]. The equilibrium yields from 2:1 $\mathrm{H}_{2}: \mathrm{CO}$ mixtures ${ }^{\ddagger}$ are shown as a function of temperature and pressure in Figure 6. As indicated in the figure, operating conditions for the current technology are pressures of 50-100 bar and temperatures of ca. $250^{\circ} \mathrm{C}$. These conditions can theoretically result in per pass methanol yields in the range of 55-75\%. Prior to World War II, less active catalysts were available and higher temperatures and pressures were required to achieve similar results.

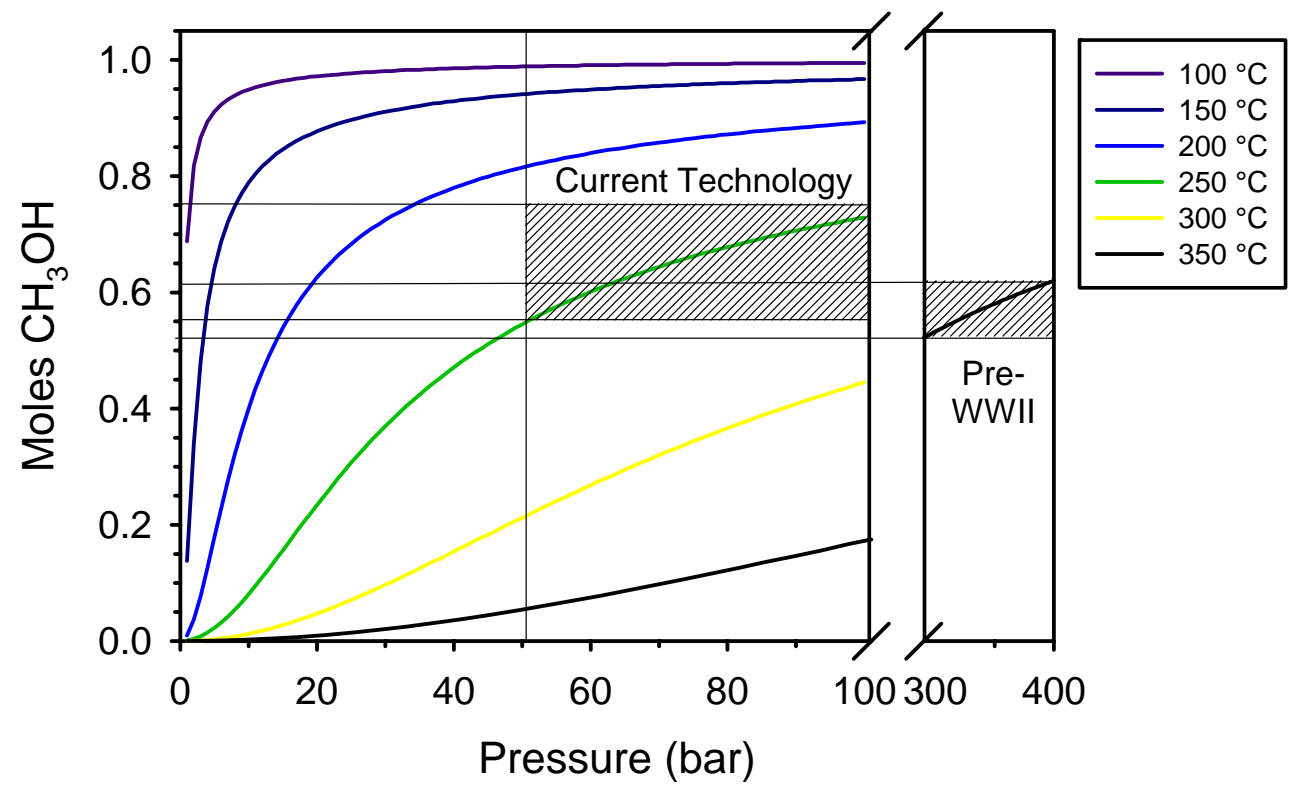

Figure 6. Thermodynamic equilibria for methanol synthesis from syngas $2 \mathrm{H}_{2}+\mathrm{CO}=\mathrm{CH}_{3} \mathrm{OH}$.

Figures 7 and 8 illustrate the equilibrium maximum methanol yields that could be expected from 3:1 mixtures of $\mathrm{H}_{2}$ and $\mathrm{CO}_{2}$ and 2:3 mixtures of $\mathrm{H}_{2} \mathrm{O}$ and $\mathrm{CO}$ respectively. The $250^{\circ} \mathrm{C}$ syngas curve and the "yield window" from Figure 6 is also shown in each figure for comparison. Figure 7 reveals that the possible equilibrium yields with the $\mathrm{H}_{2}$ based approach fall far short of those achievable with syngas under similar conditions. Figure 8, however, indicates that potential per-pass yields with CO-based chemistry can exceed $50 \%$ at reasonable temperatures and pressures (i.e. $250{ }^{\circ} \mathrm{C}, 100 \mathrm{bar}$ ). Again, the reason for this difference can be traced to the basic thermodynamics of $\mathrm{H}_{2} \mathrm{O}$ and $\mathrm{CO}_{2}$. Both gas mixes $\mathrm{H}_{2} / \mathrm{CO}_{2}$ and $\mathrm{H}_{2} \mathrm{O} / \mathrm{CO}$ contain excess oxygen atoms relative to the stoichiometry of methanol. If methanol is produced, the excess oxygen must find its way into a coproduct. In the case of $\mathrm{H}_{2} / \mathrm{CO}_{2}$, the coproduct is water; in the case of $\mathrm{H}_{2} \mathrm{O} / \mathrm{CO}$, the coproduct is $\mathrm{CO}_{2}$. At the temperature of methanol synthesis, $\mathrm{CO}_{2}$ is

\footnotetext{
\# “Real” feeds do not contain only $\mathrm{CO}$ and $\mathrm{H}_{2}$. One way to account for the WGS reaction is to define a stoichiometric number as $\left(\mathrm{H}_{2}-\mathrm{CO}_{2}\right) /\left(\mathrm{CO}+\mathrm{CO}_{2}\right)$. The ideal stoichiometric number is 2 [2].
} 
thermodynamically more stable than $\mathrm{H}_{2} \mathrm{O}$ (Figure 1 ), hence the CO-based route is the more favorable alternate (non-syngas) route from an equilibrium standpoint.

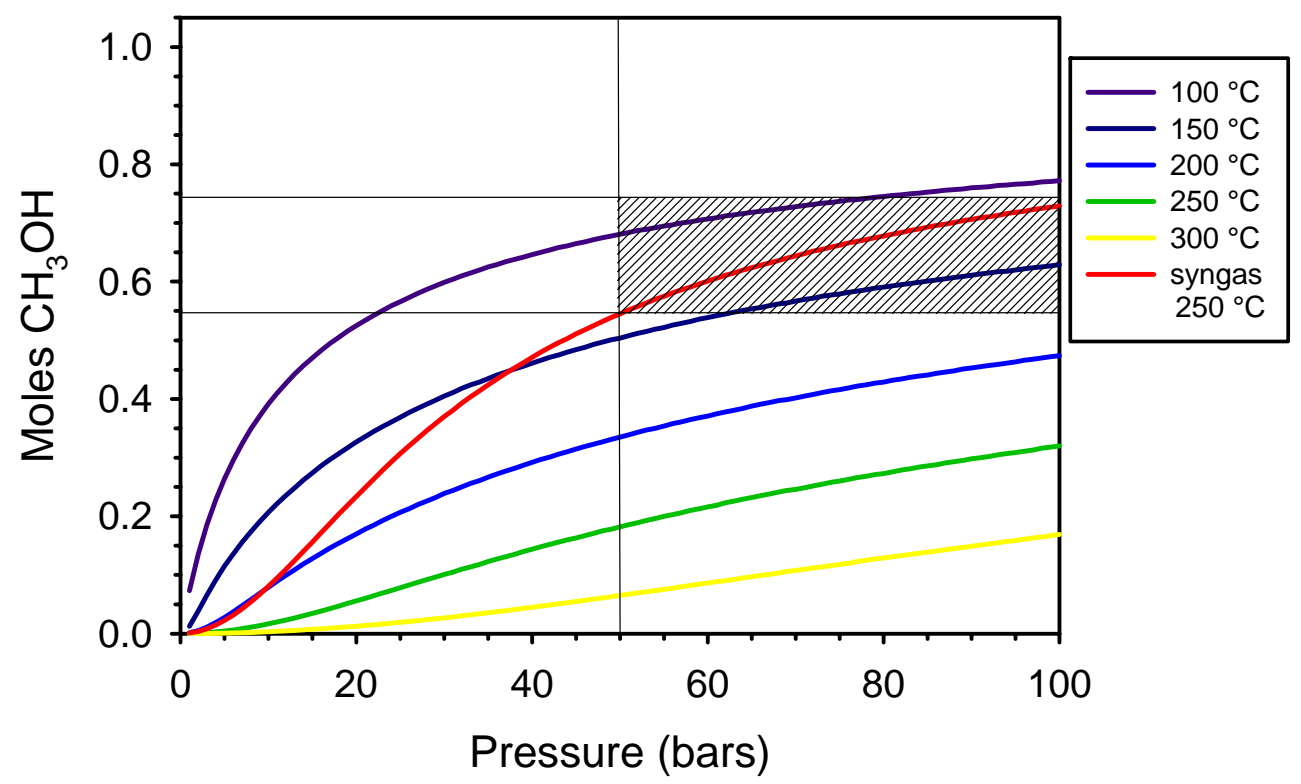

Figure 7. Thermodynamic equilibria for methanol synthesis from $\mathrm{H}_{2}$ and $\mathrm{CO}_{2}$. $3 \mathrm{H}_{2}+\mathrm{CO}_{2}=\mathrm{CH}_{3} \mathrm{OH}+$ $\mathrm{H}_{2} \mathrm{O}(\mathrm{g})$.

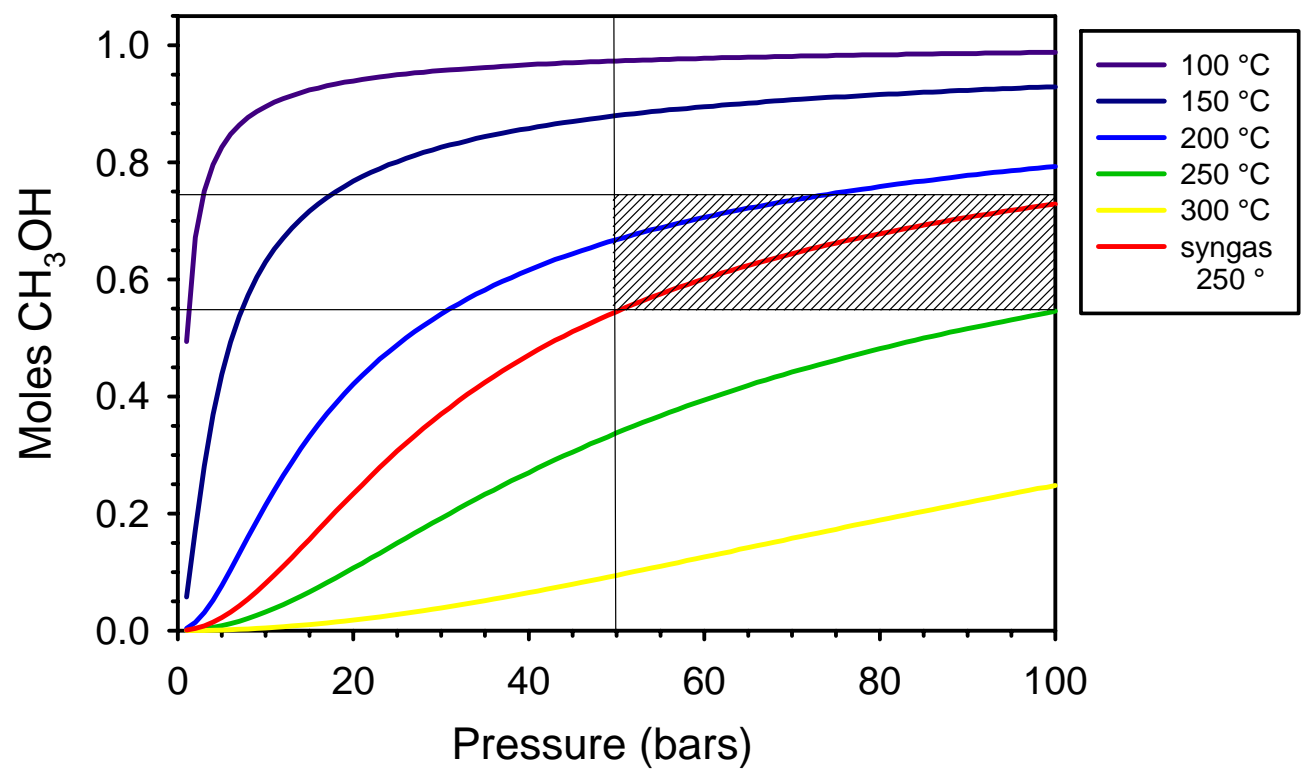

Figure 8. Thermodynamic equilibria for methanol synthesis from $\mathrm{H}_{2} \mathrm{O}$ and $\mathrm{CO} .2 \mathrm{H}_{2} \mathrm{O}(\mathrm{g})+3 \mathrm{CO}=$ $\mathrm{CH}_{3} \mathrm{OH}+2 \mathrm{CO}_{2}$.

In practice, per-pass conversions for methanol from syngas are significantly less than theoretical. Reported conversions range anywhere from only 15-25\% [3] to as high as $40 \%$ [4] or $50 \%$ (with advanced catalysts) [5]. One limiting factor is the exotherm of the reaction which drives a temperature increase. The temperature increase suppresses the potential conversion, but conversion may also be intentionally limited to minimize the increase. There are several reactor design strategies for mitigating this effect, one of the 
most advanced being the $\mathrm{LPMeOH}$ (liquid-phase methanol) reactor. In this case, the reaction is carried out in a large volume of inert liquid in which the catalyst is slurried. The large thermal mass of the inert prevents hot spots from developing and minimizes the overall temperature rise. A second strategy for improving per-pass conversions is the development of catalysts with improved activity as lower temperatures. Some progress in this regard has been reported, but evidently the materials rapidly deactivate [6].

\section{Reaction Rates for Methanol Synthesis}

Industrial syngas-to-methanol processes presently all rely on copper-based catalysts. The gas-phase ICI (now Synetix) process, which accounts for more than half of installed capacity, is based on a $\mathrm{Cu} / \mathrm{ZnO} / \mathrm{Al}_{2} \mathrm{O}_{3}$ catalyst [1]. Due to the maturity of the process the catalytic processes are well characterized if not fully understood and as such numerous kinetic models of methanol synthesis have been published. The steady-state model of Bussche and Froment [7] was formulated to be consistent with known reaction mechanisms occurring over $\mathrm{Cu} / \mathrm{ZnO} / \mathrm{Al}_{2} \mathrm{O}_{3}$ and was recently applied to perform initial cost estimates for converting $\mathrm{H}_{2}$ and $\mathrm{CO}_{2}$ to methanol [8].

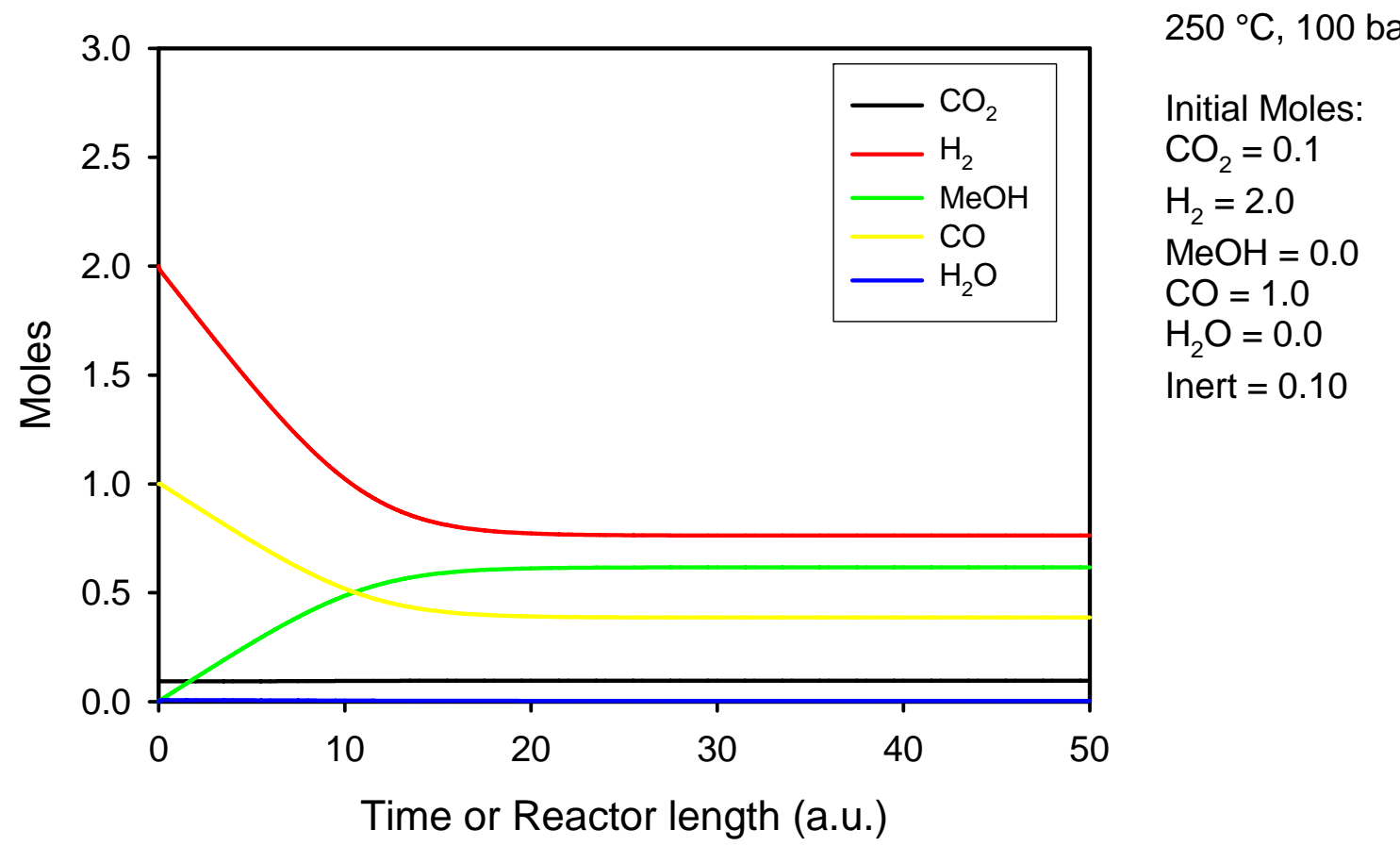

Figure 9. Calculated conversion of $\mathrm{CO}_{2}$-containing synthesis gas to methanol over $\mathrm{Cu} / \mathrm{ZnO} / \mathrm{Al}_{2} \mathrm{O}_{3}$.

We have implemented a simplified version of the model in Sigmaplot (the reaction is treated as isothermal and isobaric) to provide an initial evaluation of the plausibility of methanol synthesis from alternate feeds by comparing results for syngas, $\mathrm{H}_{2} / \mathrm{CO}_{2}$ mixtures, and $\mathrm{H}_{2} \mathrm{O} / \mathrm{CO}$ mixtures. The model of a fixed-bed gas-phase plug flow reactor is based on reaction equilibria and rate equations for two different reactions of $\mathrm{CO}_{2}$ : the RWGS reaction and the direct hydrogenation of $\mathrm{CO}_{2}$ to methanol. ${ }^{\S}$ The basic rate equations, material balances, and parameters used here are provided as Appendix A.

\footnotetext{
$\S$ There is ample evidence suggesting that $\mathrm{CO}_{2}$, rather than $\mathrm{CO}$, is the direct precursor to methanol on the catalyst surface, e.g. through the formation of surface carbonates and formates.
} 
The modeling results, normalized to a fixed catalyst loading, are presented in Figures 914. The results for a syngas feed containing a small fraction of $\mathrm{CO}_{2}$ are presented in Figure 9. In this case, the reaction proceeds rapidly to the equilibrium composition. For Figure 10, the concentration of $\mathrm{CO}_{2}$ in the feed is reduced by a factor of 10 . In this case, the reaction is significantly more sluggish, reflecting the importance of $\mathrm{CO}_{2}$ as a precursor to methanol. For Figure 11, the feed is again deficient in $\mathrm{CO}_{2}$, but a small quantity of steam has been added to the feed. In this case, the evolution of methanol closely tracks that seen in Figure 9. This results from the initial rapid WGS reaction of $\mathrm{H}_{2} \mathrm{O}$ and $\mathrm{CO}$ steam to form $\mathrm{H}_{2}$ and the necessary $\mathrm{CO}_{2}$.

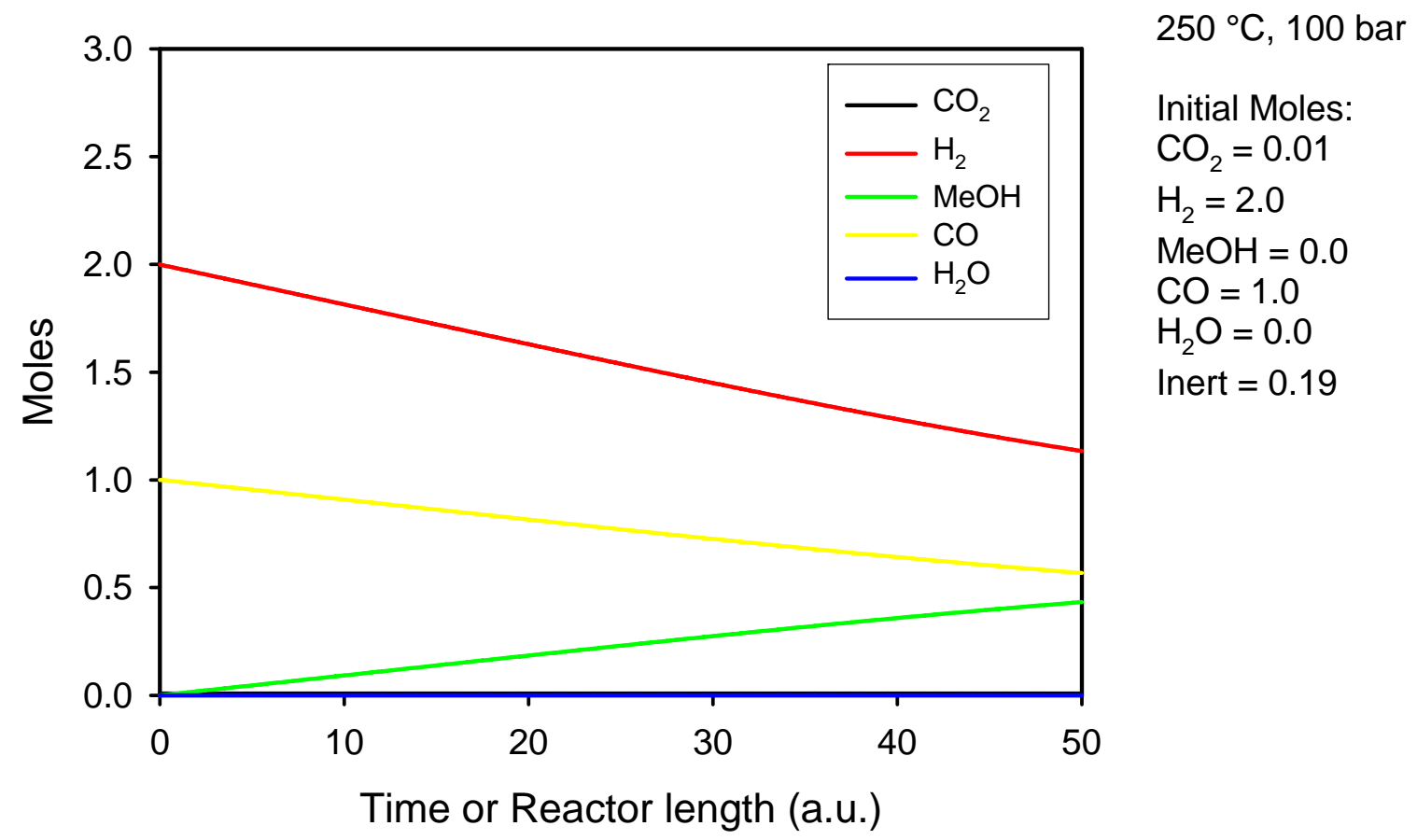

Figure 10. Calculated conversion of synthesis gas to methanol over $\mathrm{Cu} / \mathrm{ZnO} / \mathrm{Al}_{2} \mathrm{O}_{3}$. Syngas feed is dry and $\mathrm{CO}_{2}$ deficient.

Results for a feed of 3:1 $\mathrm{H}_{2}: \mathrm{CO}_{2}$ are presented in Figure 12. In this case, the RWGS reaction results in an initial rapid conversion of $\mathrm{H}_{2}$ and $\mathrm{CO}_{2}$ to $\mathrm{CO}$ and $\mathrm{H}_{2} \mathrm{O}$. However, conversion to methanol is very slow despite the large amount of unconverted $\mathrm{CO}_{2}$ remaining. Figure 13 shows that the kinetics are so sluggish that increasing the reactor length (or increasing the residence time) by a factor of four does not quite lead to an equilibrium mixture in the effluent. The reason underlying the sluggish kinetics is that water, a necessary co-product if $\mathrm{CO}_{2}$ is to be the source of carbon, acts as an inhibitor on the catalyst. Note that the small amount of water was not an issue in Figure 11 because in that case it was rapidly consumed by WGS rather than produced by RWGS. 


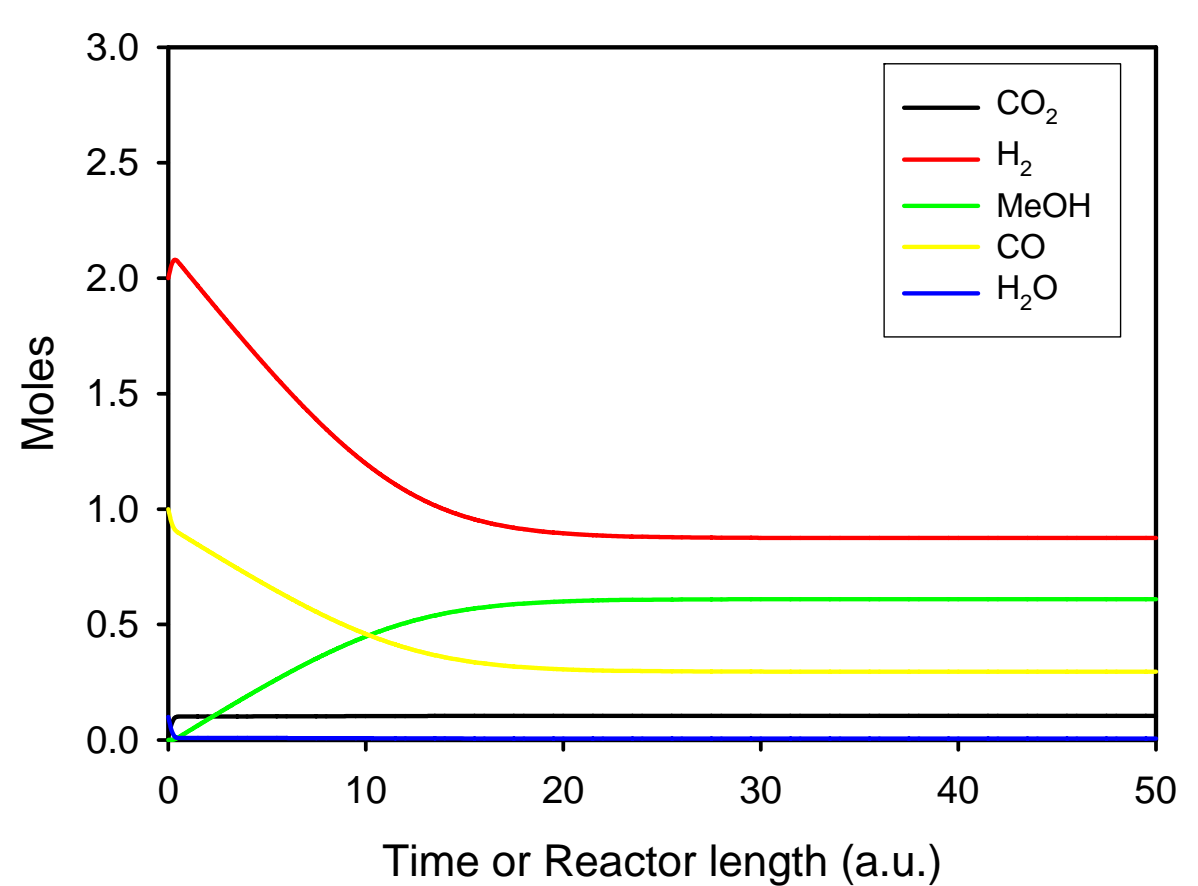

$250^{\circ} \mathrm{C}, 100$ bar

Initial Moles:

$\mathrm{CO}_{2}=0.01$

$\mathrm{H}_{2}=2.0$

$\mathrm{MeOH}=0.0$

$\mathrm{CO}=1.0$

$\mathrm{H}_{2} \mathrm{O}=0.1$

Inert $=0.09$

Figure 11. Calculated conversion of synthesis gas to methanol over $\mathrm{Cu} / \mathrm{ZnO} / \mathrm{Al}_{2} \mathrm{O}_{3}$. Syngas feed is $\mathrm{CO}_{2}$ deficient, but moist.

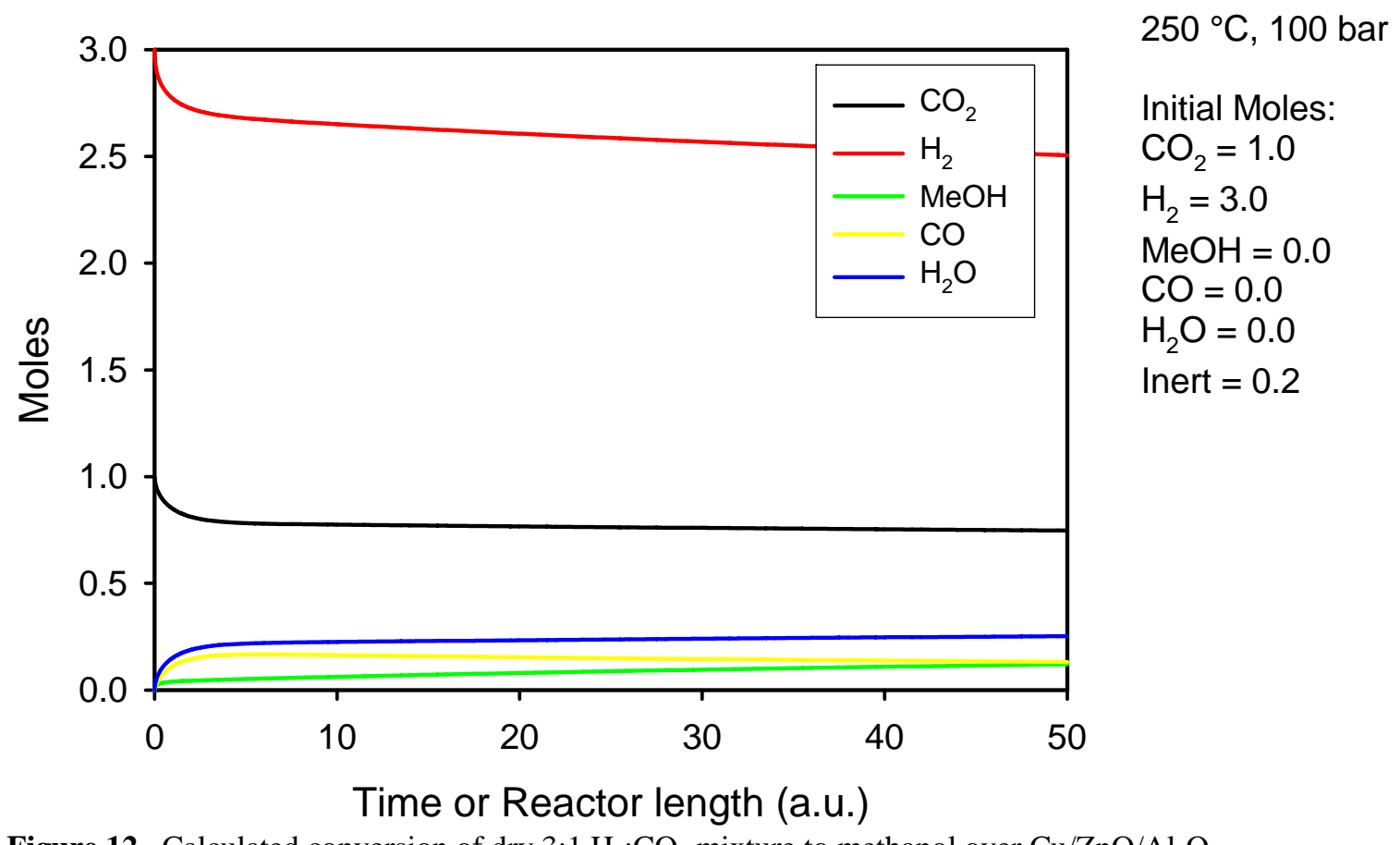

Figure 12. Calculated conversion of dry $3: 1 \mathrm{H}_{2}: \mathrm{CO}_{2}$ mixture to methanol over $\mathrm{Cu} / \mathrm{ZnO} / \mathrm{Al}_{2} \mathrm{O}_{3}$. 


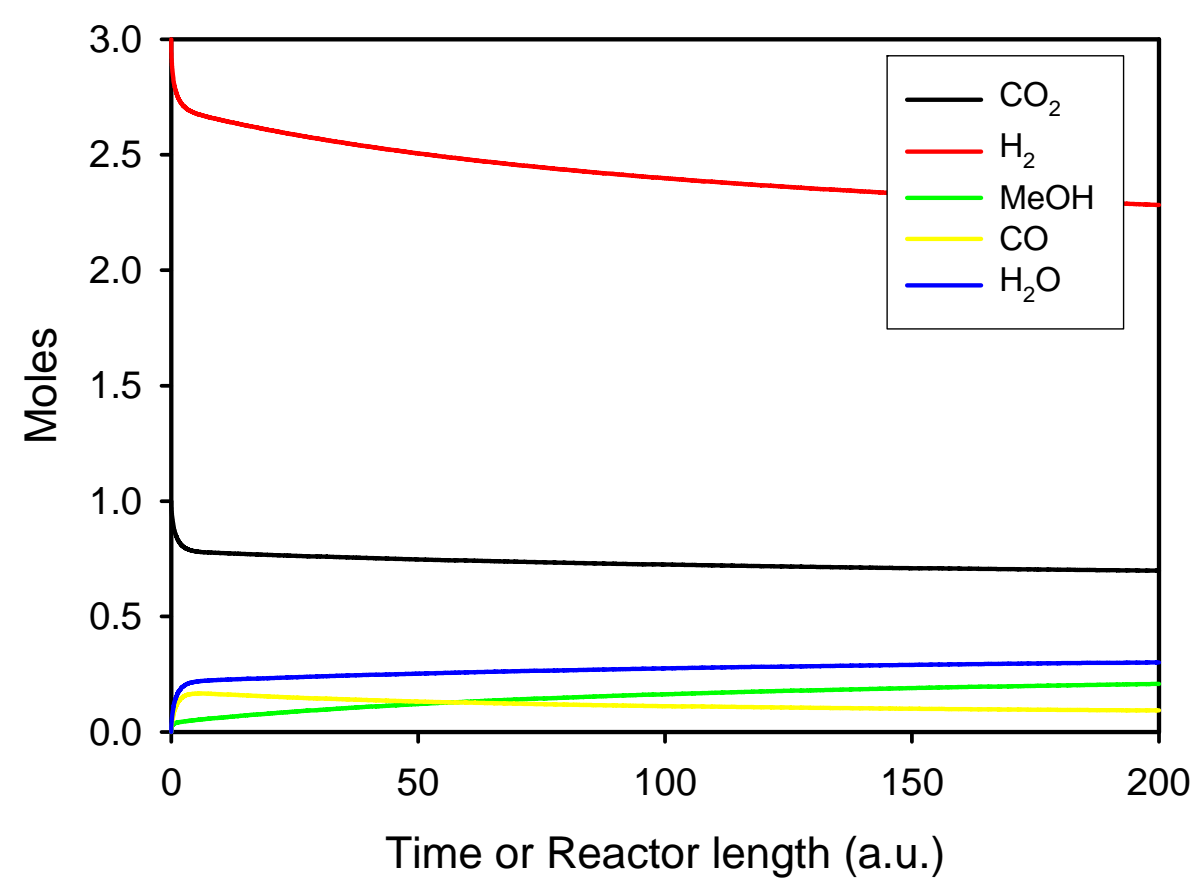

$250^{\circ} \mathrm{C}, 100$ bar

Initial Moles:

$\mathrm{CO}_{2}=1.0$

$\mathrm{H}_{2}=3.0$

$\mathrm{MeOH}=0.0$

$\mathrm{CO}=0.0$

$\mathrm{H}_{2} \mathrm{O}=0.0$

Inert $=0.20$

Figure 13. Calculated conversion of dry 3:1 $\mathrm{H}_{2}: \mathrm{CO}_{2}$ mixture to methanol over $\mathrm{Cu} / \mathrm{ZnO} / \mathrm{Al}_{2} \mathrm{O}_{3}$. Reactor (or residence time) has been lengthened by a factor of 4 to further illustrate sluggish kinetics.

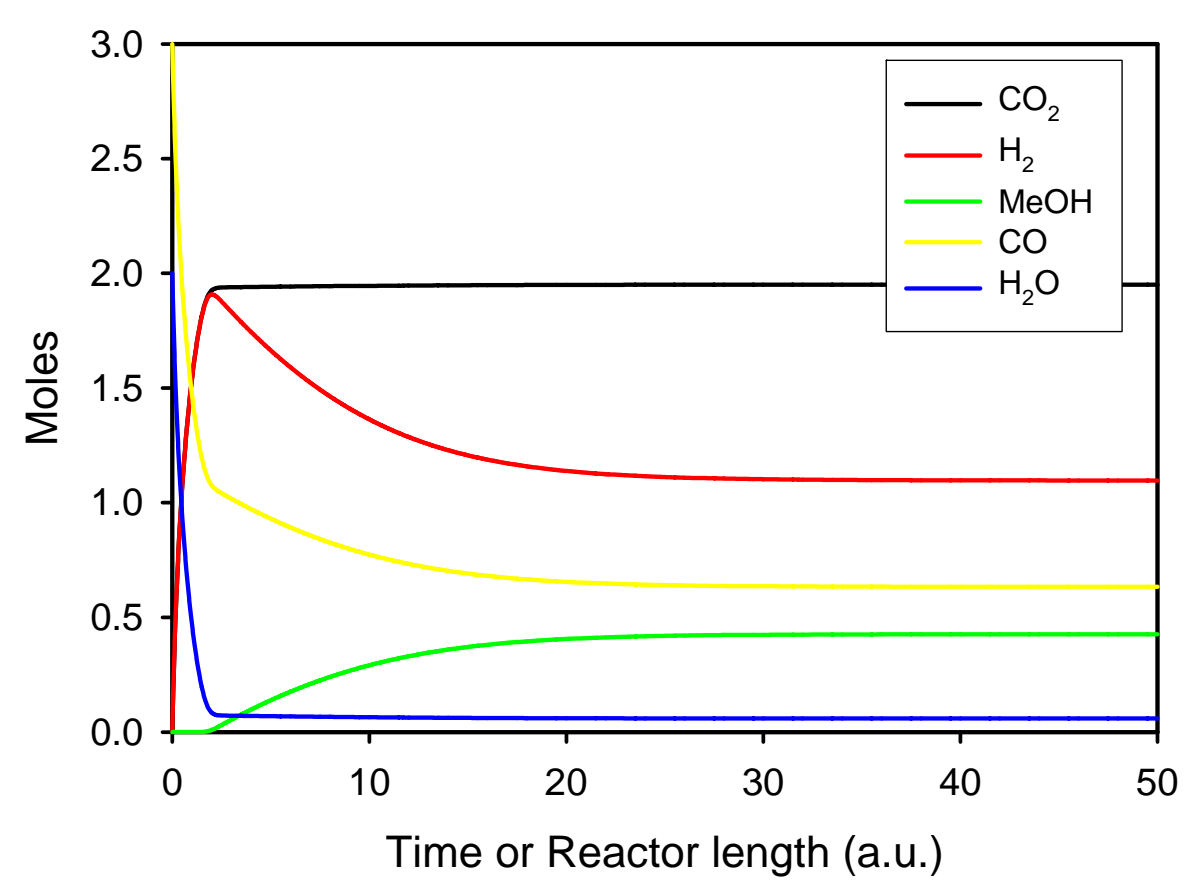

$250{ }^{\circ} \mathrm{C}, 100$ bar

Initial Moles:

$\mathrm{CO}_{2}=0.01$

$\mathrm{H}_{2}=0.01$

$\mathrm{MeOH}=0.0$

$\mathrm{CO}=3.0$

$\mathrm{H}_{2} \mathrm{O}=2.0$

Inert $=0.18$

Figure 14. Calculated conversion of $3: 2 \mathrm{CO}: \mathrm{H}_{2} \mathrm{O}$ mixture to methanol over $\mathrm{Cu} / \mathrm{ZnO} / \mathrm{Al}_{2} \mathrm{O}_{3}$.

Figure 14 shows results for a 3:2 feed of $\mathrm{CO}$ and $\mathrm{H}_{2} \mathrm{O}$. In this case, there is again an initial rapid WGS reaction that results in the conversion of $\mathrm{CO}$ and $\mathrm{H}_{2} \mathrm{O}$ into $\mathrm{CO}_{2}$ and $\mathrm{H}_{2}$. Although the consumption of water is not complete, it is evidently sufficient as the subsequent production of methanol proceeds apace. Unlike water, the presence of a large excess of $\mathrm{CO}_{2}$ does not appear to be problematic, at least in this model. Hence, the 
Bussche/Froment model indicates that from a reaction rate point of view, a mixture of $\mathrm{CO}$ and $\mathrm{H}_{2} \mathrm{O}$, while not as good as syngas, is again significantly better than a mixture of $\mathrm{CO}_{2}$ and $\mathrm{H}_{2}$ for methanol production. Clearly this conclusion needs validation.

Japanese researchers [9] and more recently others [10] have developed alternate catalysts for synthesizing methanol from $\mathrm{CO}_{2}$ and $\mathrm{H}_{2}$. The Japanese catalysts are $\mathrm{Cu}-\mathrm{Zn}$-based, but contain a variety of additives in addition to alumina including $\mathrm{ZrO}_{2}, \mathrm{Ga}_{2} \mathrm{O}_{3}$, and $\mathrm{SiO}_{2}$. Oddly, the list of properties the additives address, namely specific activity, active surface area (dispersion), thermal stability, and long term stability (sintering of support and active phases), does not include improved water tolerance. Clearly this was known to be an issue as experiments were done to show the negative effect of water on a $\mathrm{Cu} / \mathrm{ZnO} / \mathrm{ZrO}_{2}$ catalyst. Similar experiments are not reported for the 4 and 5 component catalysts. Thus, it is not clear whether the advanced catalysts address the water issue. Per pass yields reported for the advanced catalyst are low (10\%). We have repeated the modeling cases illustrated in Figures 9-14 using a model developed for one of the advanced Japanese formulations [11]. In general, the trends in the two models are similar, but the equilibrium conversions predicted by the model of Kubota el al. are a little higher. The notable exception is that the Japanese model does not indicate significant inhibition by water. It is not clear whether this is actually a representative result for the multicomponent catalyst or the result of applying the model beyond its applicable range The full set of results and further discussion are presented in Appendix B.

\section{Thermodynamics of Dimethyl Ether (DME) Synthesis}

Dimethyl ether (DME) has attracted interest as a clean-burning substitute for diesel. Similar to LPG, DME must be slightly pressurized for storage (saturated vapor pressure is $6.1 \mathrm{~atm}$ ), but it has a higher cetane number (55-60) than LPG (5-10), methanol (5), or diesel fuel (40-55). The energy density is higher on a mass and volumetric (as liquid) basis than methanol [12].

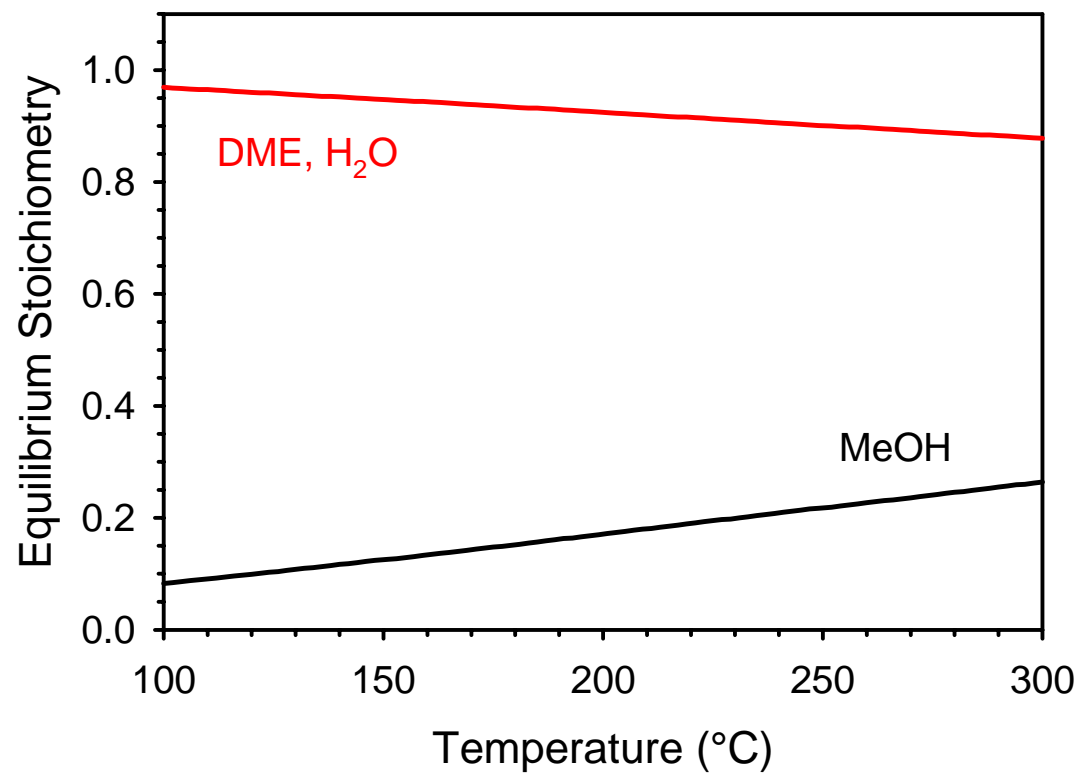

Figure 15. Thermodynamic equilibria as a function of temperature for methanol dehydration to DME $\left(2 \mathrm{CH}_{3} \mathrm{OH} \leftrightarrow \mathrm{CH}_{3} \mathrm{OCH}_{3}+\mathrm{H}_{2} \mathrm{O}\right)$. Pressure has little effect on the equilibrium. 
The traditional route to DME is the dehydration of methanol over an acid catalyst.

$$
2 \mathrm{CH}_{3} \mathrm{OH} \leftrightarrow \mathrm{CH}_{3} \mathrm{OCH}_{3}+\mathrm{H}_{2} \mathrm{O}
$$

However, if acidic functionality is included along with a methanol synthesis/WGS catalyst, the complete synthesis can be performed in a single reactor starting from syngas. This process intensification is interesting not only because the number of reactors is reduced, but also because the favorable thermodynamics (equilibria) of the dehydration reaction (Figure 15) can be used to drive to the methanol synthesis reaction, thereby increasing reactor productivity.

Another interesting twist to DME production is that there are two possible reactions:

1) $2 \mathrm{CO}+4 \mathrm{H}_{2} \leftrightarrow \mathrm{CH}_{3} \mathrm{OCH}_{3}+\mathrm{H}_{2} \mathrm{O}$

2) $3 \mathrm{CO}+3 \mathrm{H}_{2} \leftrightarrow \mathrm{CH}_{3} \mathrm{OCH}_{3}+\mathrm{CO}_{2}$

The equilibrium conversions for these two reactions are presented in Figures 16 and 17.

There are at least three important observations that can be made from a comparison of Figures 16 and 17. First, the equilibrium yields for either feed mixture, particularly the higher temperature yields, generally exceed those for methanol. Second, for a given temperature, the yields are higher for the 1:1 CO: $\mathrm{H}_{2}$ mixtures than for the 1:2 mixtures. As in earlier discussions, this can be attributed to the greater thermodynamic stability of $\mathrm{CO}_{2}$ as compared to $\mathrm{H}_{2} \mathrm{O}$ at the temperatures of interest. That is, the oxidation of $\mathrm{CO}$ is more favorable than the oxidation of $\mathrm{H}_{2}$ at these temperatures (Figure 1). Finally, the results have less pressure dependence than is observed for methanol synthesis.

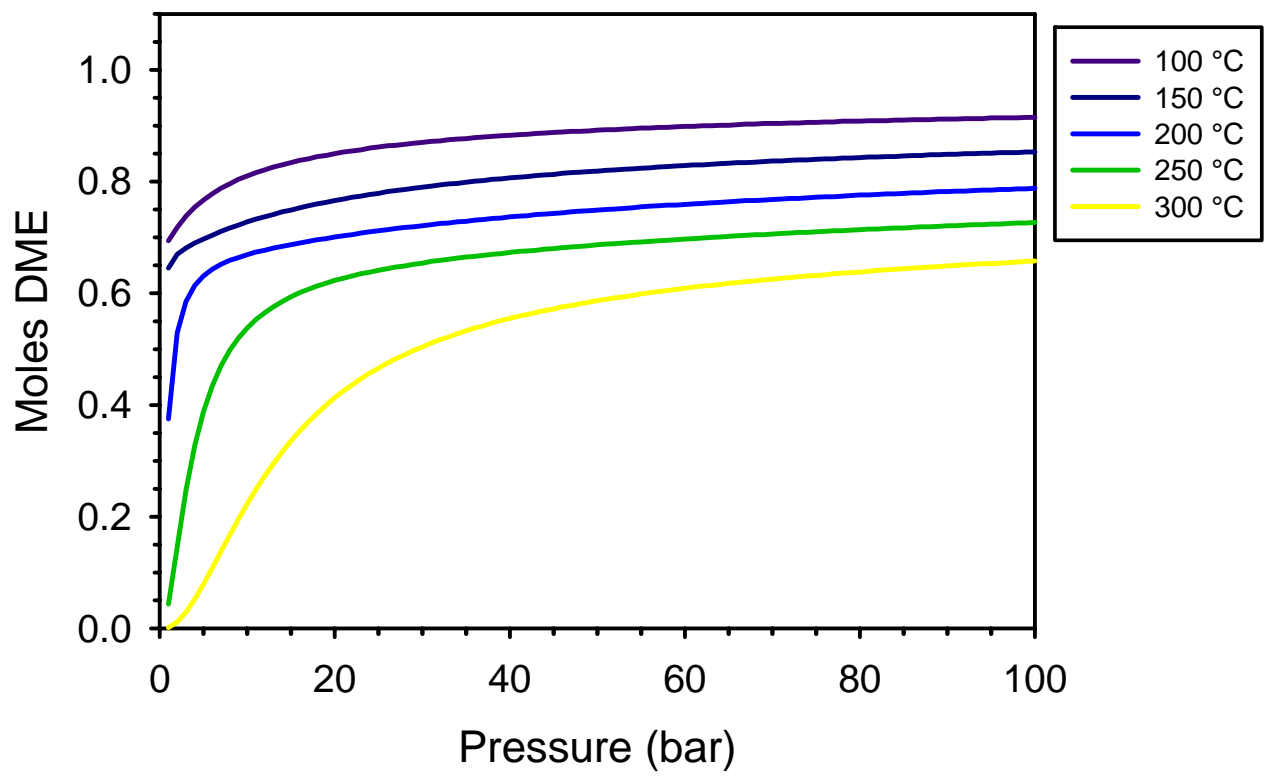

Figure 16. Thermodynamic equilibria as a function of temperature and pressure for DME synthesis from syngas with water as a co-product $\left(2 \mathrm{CO}+4 \mathrm{H}_{2} \leftrightarrow \mathrm{CH}_{3} \mathrm{OCH}_{3}+\mathrm{H}_{2} \mathrm{O}\right)$. 


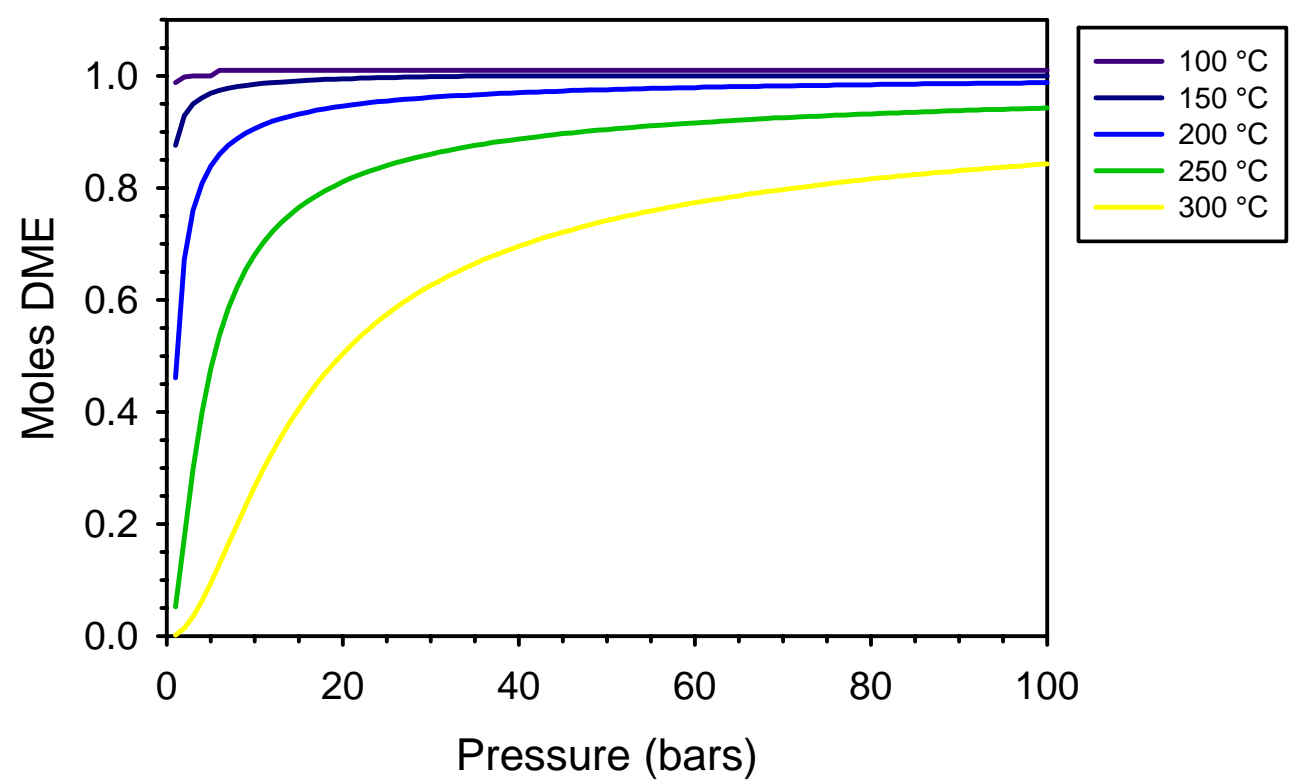

Figure 17. Thermodynamic equilibria as a function of temperature and pressure for DME synthesis from syngas with carbon dioxide as a co-product $\left(3 \mathrm{CO}+3 \mathrm{H}_{2} \leftrightarrow \mathrm{CH}_{3} \mathrm{OCH}_{3}+\mathrm{CO}_{2}\right)$

The results for a 3:1 Feed of $\mathrm{H}_{2}$ and $\mathrm{CO}_{2}$ are presented in Figure 18. In this case, the gains achievable over methanol synthesis are marginal, being roughly $5 \%$ net increase for a given temperature at 100 bars. The curves are somewhat flatter though and the gains are more significant at lower pressures. The results for a 2:1 CO: $\mathrm{H}_{2} \mathrm{O}$ feed are shown in Figure 19. In this case the yields are not quite as good as those for the $\mathrm{CO}_{2}$-yielding syngas route, but they greatly exceed those possible with $\mathrm{CO}_{2}$ and $\mathrm{H}_{2}$ mixtures, and also exceed those from the water-yielding syngas route. The advantage over the syngas route increases at lower temperatures.

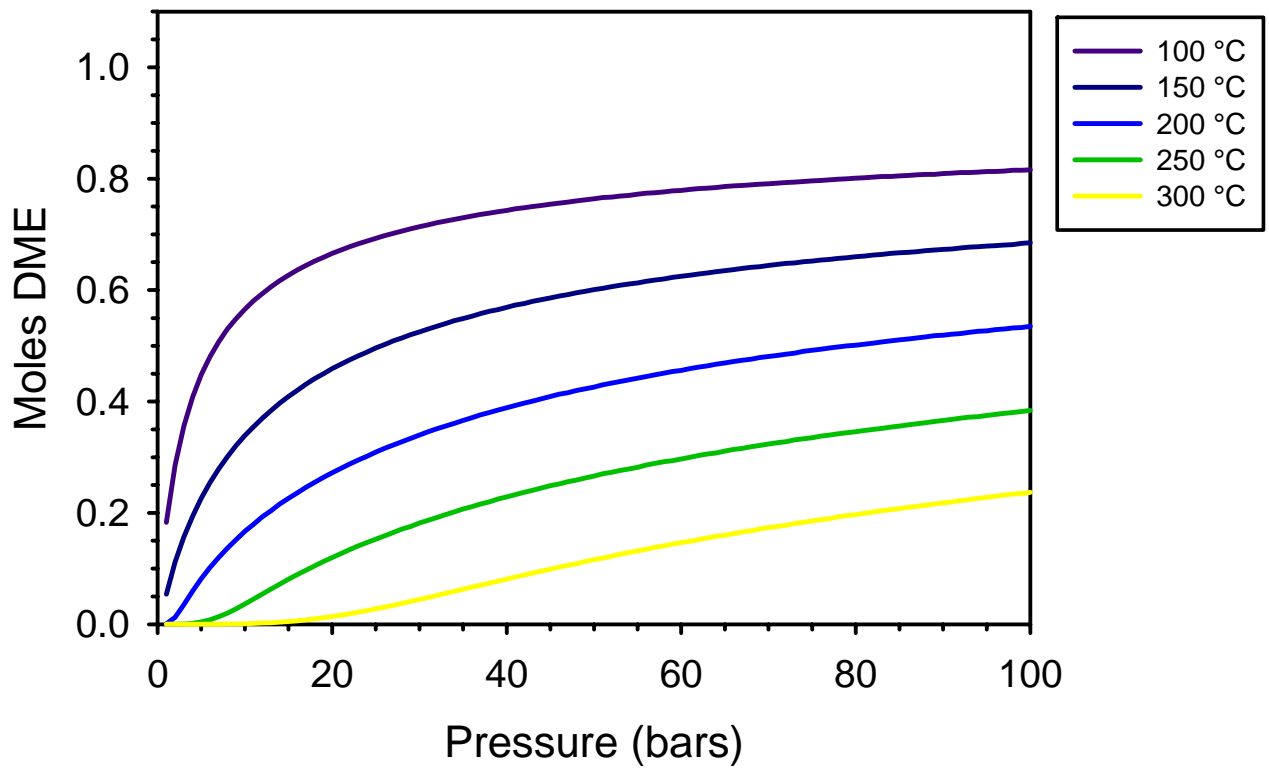

Figure 18. Thermodynamic equilibria as a function of temperature and pressure for DME synthesis from a 3:1 mixture of $\mathrm{H}_{2}$ and $\mathrm{CO}_{2}\left(2 \mathrm{CO}_{2}+6 \mathrm{H}_{2} \leftrightarrow \mathrm{CH}_{3} \mathrm{OCH}_{3}+3 \mathrm{H}_{2} \mathrm{O}\right)$. 
There is a second potential advantage of the $\mathrm{CO}$ and $\mathrm{H}_{2} \mathrm{O}$ route over the water-yielding syngas route and it again stems from the presence of water. In some cases the acid functionality of some materials can be rendered inactive by excess water [13]. Thus, in this case, the produced water is a potential issue for both the Cu-based methanol synthesis catalyst and the acidic dehydration catalyst. In the case of the $\mathrm{CO} / \mathrm{H}_{2} \mathrm{O}$ feed, the WGS reaction consumes water, potentially mitigating this problem. Of course, the $\mathrm{CO}_{2}$-yielding syngas route likely negates this potential advantage. Also, the complete absence of water can in some cases also lead to catalyst deactivation through coking [13].

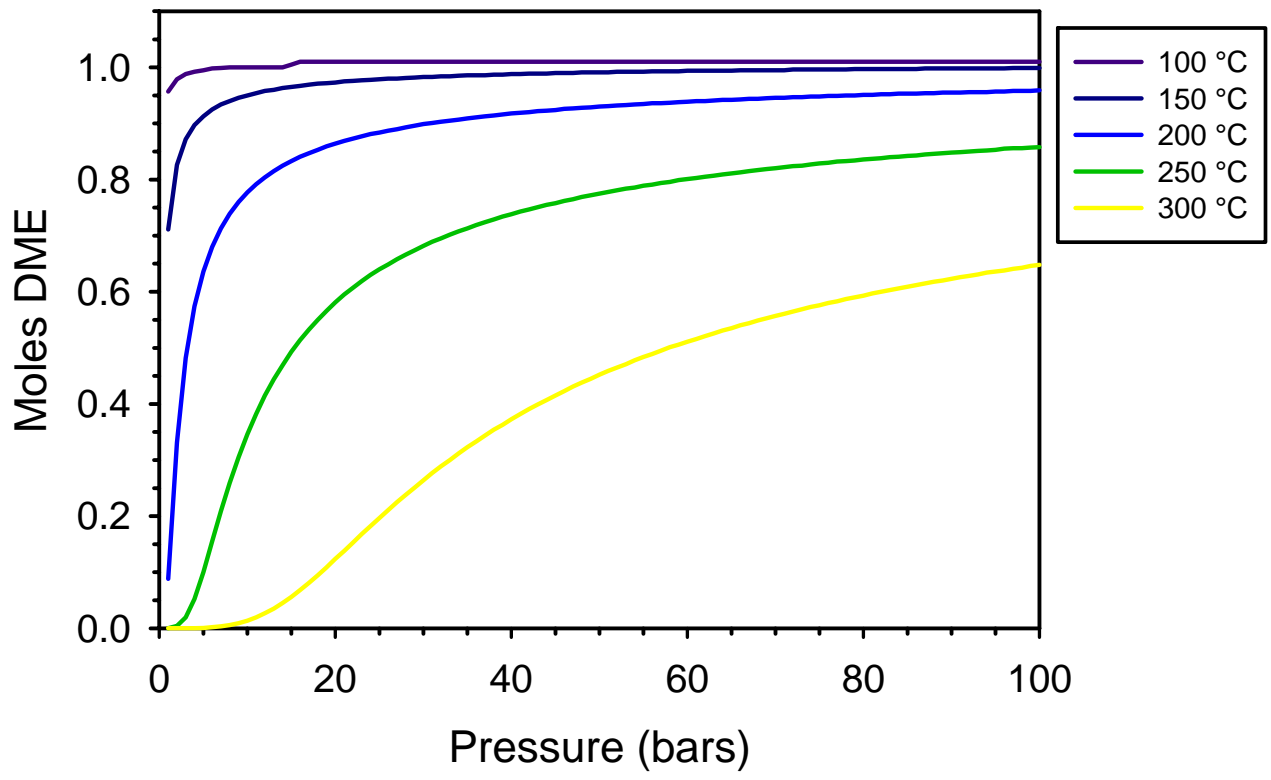

Figure 19. Thermodynamic equilibria as a function of temperature and pressure for DME synthesis from a 2:1 mixture of $\mathrm{CO}$ and $\mathrm{H}_{2} \mathrm{O}\left(6 \mathrm{CO}+3 \mathrm{H}_{2} \mathrm{O} \leftrightarrow \mathrm{CH}_{3} \mathrm{OCH}_{3}+4 \mathrm{CO}_{2}\right)$.

\section{Additional Thermodynamic Considerations}

One of the practical difficulties of large-scale methanol synthesis is that the reaction is exothermic. Successfully managing the heat is a key to achieving high yields as the equilibrium becomes more unfavorable as temperature increases. There are several different approaches to this including the use of multiple reactors with cooling between sections, intermittent gas injection along the length of the reactor, and a unique annular design with external cooling and internal heat exchange that also preheats the reactor feed [5]. Carrying out the reaction using a slurry catalyst in an inert liquid phase acting as a thermal sink and heat transfer fluid as in the LPMeOH or LPDME process is one option that seems very promising [14]. The large thermal mass and intimate contact between the inert liquid phase and the reacting gaseous phase does much to minimize the temperature rise and increase yields.

The basic thermodynamics of the different reactions discussed herein are compared in Table 1. It is clear from the table that thermal management will be an even more important consideration for the most attractive alternatives to methanol from syngas discussed above. For example, the heat released for methanol synthesis from $\mathrm{CO}$ and 
$\mathrm{H}_{2} \mathrm{O}$ is almost double that for methanol from syngas. The situation for syngas to DME and $\mathrm{CO}_{2}$ is worse, with higher potential yields and an exotherm that is more than 2.5 times greater than that for methanol synthesis. Worse yet is DME synthesis from CO and $\mathrm{H}_{2} \mathrm{O}$ for which the exotherm is up to 4 times greater than that for methanol from syngas. Clearly if the advanced options discussed herein are to be successfully implemented, clever reactor designs to manage the heat evolution will be crucial.

Table 1. Thermodynamics of reactions relevant to methanol and DME synthesis.

\begin{tabular}{|c|c|c|c|c|c|}
\hline Reaction & $25^{\circ} \mathrm{C}$ & $100^{\circ} \mathrm{C}$ & $200^{\circ} \mathrm{C}$ & $300^{\circ} \mathrm{C}$ & \\
\hline \multirow{3}{*}{$\begin{array}{c}1 \\
\text { WGS }\end{array}$} & -9.848 & -9.747 & -9.58 & -9.374 & $\Delta \mathrm{H}(\mathrm{kcal})$ \\
\hline & -10.103 & -9.797 & -9.403 & -9.008 & $\Delta \mathrm{S}(\mathrm{cal} / \mathrm{K})$ \\
\hline & -6.836 & -6.091 & -5.131 & -4.211 & $\Delta \mathrm{G}(\mathrm{kcal})$ \\
\hline \multirow{3}{*}{$\begin{array}{c}2 \\
\text { Syngas to } \\
\mathrm{MeOH}\end{array}$} & -21.62 & -22.339 & -23.134 & -23.76 & $\Delta \mathrm{H}(\mathrm{kcal})$ \\
\hline & -52.379 & -54.535 & -56.134 & -57.636 & $\Delta \mathrm{S}(\mathrm{cal} / \mathrm{K})$ \\
\hline & -6.003 & -1.989 & 3.567 & 9.274 & $\Delta \mathrm{G}(\mathrm{kcal})$ \\
\hline \multirow{3}{*}{$\begin{array}{c}3 \\
\mathrm{CO}_{2} \text { to } \mathrm{MeOH} \\
\& \mathrm{H}_{2} \mathrm{O}\end{array}$} & -11.788 & -12.591 & -13.553 & -14.386 & $\Delta \mathrm{H}(\mathrm{kcal})$ \\
\hline & -42.33 & -44.738 & -47.028 & -48.628 & $\Delta \mathrm{S}(\mathrm{cal} / \mathrm{K})$ \\
\hline & 0.833 & 4.102 & 8.698 & 13.485 & $\Delta \mathrm{G}(\mathrm{kcal})$ \\
\hline \multirow{3}{*}{$\begin{array}{c}4 \\
\mathrm{CO} \text { to } \mathrm{MeOH} \\
\& \mathrm{CO}_{2}\end{array}$} & -41.057 & -41.833 & -42.295 & -42.507 & $\Delta \mathrm{H}(\mathrm{kcal})$ \\
\hline & -72.477 & -74.130 & -75.238 & -75.652 & $\Delta \mathrm{S}(\mathrm{cal} / \mathrm{K})$ \\
\hline & -19.676 & -14.172 & -6.696 & 0.853 & $\Delta \mathrm{G}(\mathrm{kcal})$ \\
\hline \multirow{3}{*}{$\begin{array}{c}5 \\
\mathrm{MeOH} \text { to } \\
\mathrm{DME} \& \mathrm{H}_{2} \mathrm{O}\end{array}$} & -5.706 & -5.516 & -5.310 & -5.158 & $\Delta \mathrm{H}(\mathrm{kcal})$ \\
\hline & -5.580 & -5.009 & -4.517 & -4.224 & $\Delta \mathrm{S}(\mathrm{cal} / \mathrm{K})$ \\
\hline & -4.043 & -3.647 & -3.173 & -2.737 & $\Delta \mathrm{G}(\mathrm{kcal})$ \\
\hline \multirow{3}{*}{$\begin{array}{c}6 \\
\text { Syngas to } \\
\text { DME \& } \mathrm{H}_{2} \mathrm{O}\end{array}$} & -48.947 & -50.194 & -51.578 & -52.677 & $\Delta \mathrm{H}(\mathrm{kcal})$ \\
\hline & -110.337 & -114.079 & -117.379 & -119.496 & $\Delta \mathrm{S}(\mathrm{cal} / \mathrm{K})$ \\
\hline & -16.050 & -7.625 & 3.960 & 15.812 & $\Delta \mathrm{G}(\mathrm{kcal})$ \\
\hline \multirow{3}{*}{$\begin{array}{c}7 \\
\text { Syngas to } \\
\text { DME \& } \mathrm{CO}_{2} \\
\end{array}$} & -58.779 & -59.941 & -61.158 & -62.051 & $\Delta \mathrm{H}(\mathrm{kcal})$ \\
\hline & -120.386 & -123.876 & -126.782 & -28.503 & $\Delta \mathrm{S}(\mathrm{cal} / \mathrm{K})$ \\
\hline & -22.886 & -13.717 & -1.171 & 11.601 & $\Delta \mathrm{G}(\mathrm{kcal})$ \\
\hline \multirow{3}{*}{$\begin{array}{c}8 \\
\mathrm{CO}_{2} \text { to } \mathrm{DME} \\
\& \mathrm{H}_{2} \mathrm{O}\end{array}$} & -29.282 & -30.699 & -32.417 & -33.93 & $\Delta \mathrm{H}(\mathrm{kcal})$ \\
\hline & -90.240 & -94.484 & -98.572 & -101.48 & $\Delta \mathrm{S}(\mathrm{cal} / \mathrm{K})$ \\
\hline & -2.377 & 4.558 & 14.222 & 24.233 & $\Delta \mathrm{G}(\mathrm{kcal})$ \\
\hline \multirow{3}{*}{$\begin{array}{c}9 \\
\mathrm{CO} \text { to } \mathrm{DME} \& \\
\mathrm{CO}_{2}\end{array}$} & -88.276 & -89.183 & -89.899 & -90.172 & $\Delta \mathrm{H}(\mathrm{kcal})$ \\
\hline & -150.533 & -153.268 & -154.992 & -155.527 & $\Delta \mathrm{S}(\mathrm{cal} / \mathrm{K})$ \\
\hline & -43.394 & -31.991 & -16.565 & -1.031 & $\Delta \mathrm{G}(\mathrm{kcal})$ \\
\hline
\end{tabular}
1) $\mathrm{CO}+\mathrm{H}_{2} \mathrm{O}=\mathrm{CO}_{2}+\mathrm{H}_{2}$
2) $\mathrm{CO}+2 \mathrm{H}_{2}=\mathrm{CH}_{3} \mathrm{OH}$ (methanol synthesis)
3) $\mathrm{CO}_{2}+3 \mathrm{H}_{2}=\mathrm{CH}_{3} \mathrm{OH}+\mathrm{H}_{2} \mathrm{O}$
4) $3 \mathrm{CO}+2 \mathrm{H}_{2} \mathrm{O}=\mathrm{CH}_{3} \mathrm{OH}+2 \mathrm{CO}_{2}$
5) $2 \mathrm{CH}_{3} \mathrm{OH}=\mathrm{CH}_{3} \mathrm{OCH}_{3}+\mathrm{H}_{2} \mathrm{O}$ (methanol dehydration)
6) $2 \mathrm{CO}+4 \mathrm{H}_{2}=\mathrm{CH}_{3} \mathrm{OCH}_{3}+\mathrm{H}_{2} \mathrm{O}$ (dimethyl ether synthesis)
7) $3 \mathrm{CO}+3 \mathrm{H}_{2}=\mathrm{CH}_{3} \mathrm{OCH}_{3}+\mathrm{CO}_{2}$
8) $2 \mathrm{CO}_{2}+6 \mathrm{H}_{2}=\mathrm{CH}_{3} \mathrm{OCH}_{3}+3 \mathrm{H}_{2} \mathrm{O}$
9) $6 \mathrm{CO}+3 \mathrm{H}_{2} \mathrm{O}=\mathrm{CH}_{3} \mathrm{OCH}_{3}+4 \mathrm{CO}_{2}$ 


\section{Conclusions}

Thermodynamics shows that at temperatures in excess of $850^{\circ} \mathrm{C}$, carbon dioxide splitting is favored over water splitting. Additional advantages such as improved operability may also be realized, but further study and validation of the potential is required. At low temperatures, $\mathrm{CO}$ is readily converted to $\mathrm{H}_{2}$ via the WGS reaction. This suggests that CDS should be considered as a route to hydrogen. Going further, if the goal is the utilization or recycle of $\mathrm{CO}_{2}$, then there are potential further advantages to CDS over WS. Specifically, the thermodynamics of methanol and DME synthesis and possibly the kinetics of methanol synthesis are much more favorable for mixtures of $\mathrm{CO}$ and $\mathrm{H}_{2} \mathrm{O}$ than for $\mathrm{CO}_{2}$ and $\mathrm{H}_{2}$. That is, given the choice between "re-energizing" $\mathrm{CO}_{2}$ and $\mathrm{H}_{2} \mathrm{O}$ (to $\mathrm{CO}$ and $\mathrm{H}_{2}$ respectively), thermodynamic equilibria and kinetic models both strongly suggest that CDS is the better option. This is not the final word, however. Additional process considerations such as heat management (reactor design), the difficulty and energy expenditure of the separations required, the amount of gas being pressurized, recovered, and recycled, capital costs, and the amount of technology development (e.g. improvements in catalysts) required must be considered in detail and weighed for each option before a true "best-choice" is identified. These and other considerations are under investigation and will be discussed in future publications.

\section{References}

1. G.A. Olah, A. Goeppert, and G.K.S. Prakash in Beyond Oil and Gas: The Methanol Economy Wiley-VCH, New York (2006).

2. J.-P. Lange "Methanol Synthesis: A Short review of Technology Improvements" Catal. Today 64, 3 (2001).

3. X.-M. Liu, G.Q. Lu, Z.-F. Yan, J. Beltramini "Recent Advances in Catalysts for Methanol Synthesis via Hydrogenation of $\mathrm{CO}$ and $\mathrm{CO}_{2}$ ” Ind. Eng. Chem. Res. 42, 6518 (2003).

4. Sinor Synthetic Fuels Report Volume 6 No. 2 April 1999 page126. Available at http://edj.net/sinor/SFR4-99art7.html.

5. P.J.M. Tijm, F.J. Waller, D.M. Brown "Methanol Technology Developments for the New Millenium” Appl. Catal. A 221, 275 (2001).

6. M, Marchiona, M. DiGirolamo, L. Tagliabue, M.J. Spangler, T.H. Fleisch “A Review of Low Temperature Methanol Synthesis” Studies in Surface Science and Catalysis 119, 539 (1998).

7. K.M. Vanden Bussche, G.F. Froment "A Steady-State Kinetic Model for Methanol Synthesis and the Water Gas Shift Reaction on a Commercial Cu/ZnO/Al ${ }_{2} \mathrm{O}_{3}$ Catalyst” J. Catal. 161, 1 (1996).

8. D. Mignard, M. Sahibzada, J.M. Duthie, H.W. Whittington "Methanol Synthesis from FlueGas $\mathrm{CO}_{2}$ and Renewable Electricity: A Feasibility Study” Int. J. Hydrogen Energy 28, 455 (2003).

9. See for example M. Saito, T. Fujitani, M. Takeuchi, T. Watanabe "Development of Copper/Zinc Oxide-Based Multicomponent Catalysts for Methanol Synthesis from Carbon Dioxide and Hydrogen” Appl. Catal. A 138, 311 (1996).

10. See for example C. Yang, Z. Ma, N. Zhao, W. Wei, T. Hu, Y. Sun "Methanol Synthesis from $\mathrm{CO}_{2}$-Rich Syngas over a $\mathrm{ZrO}_{2}$ doped CuZnO Catalyst” Catal. Today 115, 222 (2006); J. Toyir, P.R. de la Piscina, J.L.G. Fierro, N. Homs “Catalytic Performance for $\mathrm{CO}_{2}$ Conversion to Methanol of Gallium-Promoted Copper-Based 
Catalysts : Influence of Metallic Precursors” Appl. Catal. B 34, 255 (2001); and M.

Lachowska, J. Skrzypek "Ga, Mn and Mg Promoted Coper/Zinc/Zirconia-Catalysts for Hydrogenation of Carbon Dioxide to Methanol” Studies in Surface Science and Catalysis 153, 173 (2004).

11. T. Kubota, I. Hayakawa, H. Mabuse, K. Mori, K. Ushikoshi, T. Watanabe, M. Saito "Kinetic Study of Methanol Synthesis from Carbon Dioxide and Hydrogen” Appl. Organometal. Chem, 15, 121 (2001).

12. J. Erena, R. Garoña, J.M. Arandes, A. Aguayo, J. Bilbao "Direct Synthesis of Dimethyl Ether from $\left(\mathrm{H}_{2}+\mathrm{CO}\right)$ and $\left(\mathrm{H}_{2}+\mathrm{CO}_{2}\right)$ Feeds. Effect of Feed Composition” Int. J. Chem. Reactor Eng. 3, Article A44 (2005).

13. A.T. Aguayo, J. Erena, I. Sierra, M. Olazar, J. Bilbao "Deactivation and Rgeneration of Hybrid Catalysts in the Single-Step Synthesis of Dimethyl Ether from Syngas and $\mathrm{CO}_{2}$ " Catal. Today 106, 265 (2005).

14. See for example X.D. Peng, B.A. Toseland, P.J.A. Tijm "Kinetic Understanding of the Chemical Synergy under LPDMETM Conditions - Once-Through Applications” Chem Engr. Sci. 54, 2787 (1999). 


\section{Appendix A. Reactor Modeling (Bussche and Froment)}

The model of Bussche and Froment ${ }^{* *}$ is based on two reactions of $\mathrm{CO}_{2} 1$ ) methanol synthesis, and 2) the water gas shift reaction.

1) $\mathrm{CO}_{2}+3 \mathrm{H}_{2} \leftrightarrow \mathrm{CH}_{3} \mathrm{OH}+\mathrm{H}_{2} \mathrm{O}$

2) $\mathrm{CO}_{2}+\mathrm{H}_{2} \leftrightarrow \mathrm{CO}+\mathrm{H}_{2} \mathrm{O}$

The respective reaction rates are given by the two following equations which have been subjected to validation with experimental data.

$$
\begin{aligned}
& \frac{d \beta_{1}}{d z}=r_{1}=\frac{k_{4} P_{\mathrm{CO}_{2}} P_{\mathrm{H}_{2}}\left[1-\frac{1}{k_{E 1}}\left(\frac{P_{\mathrm{H}_{2} \mathrm{O}} P_{\mathrm{CH}_{3} \mathrm{OH}}}{P_{\mathrm{H}_{2}}^{3} P_{\mathrm{CO}_{2}}}\right)\right]}{\left[1+k_{3}\left(\frac{P_{\mathrm{H}_{2} \mathrm{O}}}{P_{\mathrm{H}_{2}}}\right)+k_{1} \sqrt{P_{\mathrm{H}_{2}}}+k_{2} P_{\mathrm{H}_{2} \mathrm{O}}\right]^{3}} \\
& \frac{d \beta_{2}}{d z}=r_{2}=\frac{k_{5} P_{\mathrm{CO}_{2}}\left[1-\frac{1}{k_{\mathrm{E} 2}}\left(\frac{P_{\mathrm{H}_{2} \mathrm{O}} P_{\mathrm{CO}}}{P_{\mathrm{H}_{2}}^{3} P_{\mathrm{CO}_{2}}}\right)\right]}{\left[1+k_{3}\left(\frac{P_{\mathrm{H}_{2} \mathrm{O}}}{P_{\mathrm{H}_{2}}}\right)+k_{1} \sqrt{P_{\mathrm{H}_{2}}}+k_{2} P_{\mathrm{H}_{2} \mathrm{O}}\right]}
\end{aligned}
$$

The reaction rate constants $\left(\mathrm{k}_{1}-\mathrm{k}_{5}\right)$ and the equilibrium constants $\left(\mathrm{k}_{\mathrm{E} 1}\right.$ and $\left.\mathrm{k}_{\mathrm{E} 2}\right)$ are given as follows.

$$
\begin{aligned}
& k_{1}=0.499 e^{17197 / R T} \\
& k_{2}=6.62 \times 10^{-11} e^{124119 / R T} \\
& k_{3}=3453.38 \\
& k_{4}=1.07 e^{36696 / R T} \\
& k_{5}=1.22 \times 10^{10} e^{-94765 / R T}
\end{aligned}
$$

$$
\begin{aligned}
& k_{E 1}=10^{(3066 / T)-10.592} \\
& k_{E 2}=10^{(-2073 / T)+2.029}
\end{aligned}
$$

Following the method of Sinadinović-Fišer et al. ${ }^{\dagger \dagger}$, the number of moles of each reactant and product can be calculated from the materials balance as

$$
n_{\mathrm{CO}_{2}}=n_{\mathrm{CO}_{2}}^{0}-\beta_{1}-\beta_{2} \quad n_{\mathrm{CO}}=n_{\mathrm{CO}}^{0}+\beta_{2}
$$

\footnotetext{
${ }^{* *}$ K.M. Vanden Bussche, G.F. Froment "A Steady-State Kinetic Model for Methanol Synthesis and the Water Gas Shift Reaction on a Commercial Cu/ZnO/Al $\mathrm{O}_{3}$ Catalyst” J. Catal. 161, 1 (1996).

${ }^{+\dagger}$ S.V. Sinadinović-Fišer, M.R. Janković, R.Ž, Radičević "Simulation of the Fixed-bed Reactor for Methanol Synthesis” Petrol. and Coal 43, 31 (2001).
} 


$$
\begin{array}{ll}
n_{\mathrm{H}_{2}}=n_{\mathrm{H}_{2}}^{0}-3 \beta_{1}-\beta_{2} & n_{\mathrm{H}_{2} \mathrm{O}}=n_{\mathrm{H}_{2} \mathrm{O}}^{0}+\beta_{1}+\beta_{2} \\
n_{\mathrm{CH}_{3} \mathrm{OH}}=n_{\mathrm{CH}_{3} \mathrm{OH}}^{0}+\beta_{1} & n_{\text {total }}=n_{\mathrm{CO}_{2}}+n_{\mathrm{H}_{2}}+n_{\mathrm{CH}_{3} \mathrm{OH}}+n_{\mathrm{CO}}+n_{\mathrm{H}_{2} \mathrm{O}}+n_{\text {inert }}
\end{array}
$$

Where $n_{i}^{0}$ is the initial (feed) amount of component i. The partial pressures are then:

$$
P_{i}=P\left(\frac{n_{i}}{n_{\text {total }}}\right)
$$

The data for figures 9-14 were produced by manually integrating the rate equations and solving the material balances for discrete increments of $\Delta \mathrm{z}$. Increments in $\Delta \mathrm{z}$ of 0.01 units were typically sufficiently small to converge to a consistent result. 


\section{Appendix B. Reactor Modeling (Kubota et al.)}

The model of Kubota et al. ${ }^{\ddagger \neq}$ is based on the same two reactions of $\mathrm{CO}_{2}$ in the model of Bussche and Froment 1) methanol synthesis, and 2) the water gas shift reaction. The reaction equations were derived based on the assumption that methanol is produced through formate and methoxy intermediates and that the surface reaction between the formate and adsorbed hydrogen atoms is the rate determining step. The RWGS reaction was presumed to proceed through direct decomposition of $\mathrm{CO}_{2}$ to $\mathrm{CO}$ on the copper surface. The resulting equations were simplified by assuming that the square root of the $\mathrm{H}_{2}$ partial pressure is essentially constant, and that the partial pressure of $\mathrm{H}_{2} \mathrm{O}$ is very small relative to the partial pressure of $\mathrm{H}_{2}\left(\mathrm{P}_{\mathrm{H} 2 \mathrm{O}} / \mathrm{P}_{\mathrm{H} 2} \approx 0\right)$.

The respective reaction rates are given by the two following equations

$$
\begin{gathered}
\frac{d \beta_{1}}{d z}=R_{M}=\frac{k_{M} P_{\mathrm{CO}_{2}} P_{\mathrm{H}_{2}}\left[1-\frac{1}{K_{M}}\left(\frac{P_{\mathrm{H}_{2} \mathrm{O}} P_{\mathrm{CH}_{3} \mathrm{OH}}}{P_{\mathrm{H}_{2}}^{3} P_{\mathrm{CO}_{2}}}\right)\right]}{\left(1+K_{\mathrm{CO}_{2}} P_{\mathrm{CO}_{2}}+K_{\mathrm{H}_{2} \mathrm{O}} P_{\mathrm{H}_{2} \mathrm{O}}\right)^{2}} \\
\frac{d \beta_{2}}{d z}=R_{R}=\frac{k_{R} P_{\mathrm{CO}_{2}}\left[1-\frac{1}{K_{R}}\left(\frac{P_{\mathrm{H}_{2} \mathrm{O}} P_{\mathrm{CO}}}{P_{\mathrm{H}_{2}} P_{\mathrm{CO}_{2}}}\right)\right]}{1+K_{\mathrm{CO}_{2}} P_{\mathrm{CO}_{2}}+K_{\mathrm{H}_{2} \mathrm{O}} P_{\mathrm{H}_{2} \mathrm{O}}}
\end{gathered}
$$

The reaction rate constants $\left(\mathrm{k}_{\mathrm{M}}, \mathrm{k}_{\mathrm{R}}\right)$, adsorption equilibrium constants $\left(\mathrm{K}_{\mathrm{CO} 2}\right.$ and $\left.\mathrm{K}_{\mathrm{H} 2 \mathrm{O}}\right)$ and equilibrium constants $\left(\mathrm{K}_{\mathrm{M}}\right.$ and $\left.\mathrm{K}_{\mathrm{R}}\right)$, are given as follows.

$$
\begin{array}{ll}
k_{M}=3.261 \times 10^{4} e^{-32093 / R T} & K_{M}=10^{(7087 / T)-19.499} \\
k_{R}=1.3831 \times 10^{12} e^{-113390 / R T} & K_{R}=10^{(-4778 / T)+4.639} \\
K_{\mathrm{CO}_{2}}=0.741 & \\
K_{\mathrm{H}_{2} \mathrm{O}}=1.44511 \times 10^{-8} e^{82215.3 / R T} &
\end{array}
$$

Data for a $\mathrm{Cu} / \mathrm{ZnO} / \mathrm{ZrO}_{2} / \mathrm{Al}_{2} \mathrm{O}_{3} / \mathrm{SiO}_{2}$ catalyst was fitted to obtain the values for the rate constants and adsorption equilibrium constants.

The data for figures B1-B5 were produced by applying the method of Sinadinović-Fišer ${ }^{\S \S}$ et al. and manually integrating the rate equations and solving the material balances for discrete increments of $\Delta \mathrm{z}$. Increments in $\Delta \mathrm{z}$ of 0.00001 to 0.0001 units were typically sufficiently small to converge to a consistent result.

\footnotetext{
㧊 T. Kubota, I. Hayakawa, H. Mabuse, K. Mori, K. Ushikoshi, T. Watanabe, M. Saito "Kinetic Study of Methanol Synthesis from Carbon Dioxide and Hydrogen” Appl. Organometal. Chem, 15, 121 (2001).

${ }^{\S}$ S.V. Sinadinović-Fišer, M.R. Janković, R.Ž, Radičević "Simulation of the Fixed-bed Reactor for Methanol Synthesis” Petrol. and Coal 43, 31 (2001).
} 
Unlike the Bussche/Froment model, the Kubota model does not indicate inhibition of the reaction by water when feeding $\mathrm{CO}_{2}$ and $\mathrm{H}_{2}$. It is not clear whether this is indicative of the catalyst having enhanced water tolerance, or whether this is simply the result of extending the model past its predictive capability. Certainly as can be seen in Figure B4 as conversion increases for $\mathrm{CO}_{2}$ and $\mathrm{H}_{2}$ feed, the assumption that $\mathrm{P}_{\mathrm{H} 2 \mathrm{O}} / \mathrm{P}_{\mathrm{H} 2} \approx 0$ would begin to break down. Thus experimental validation will be required.

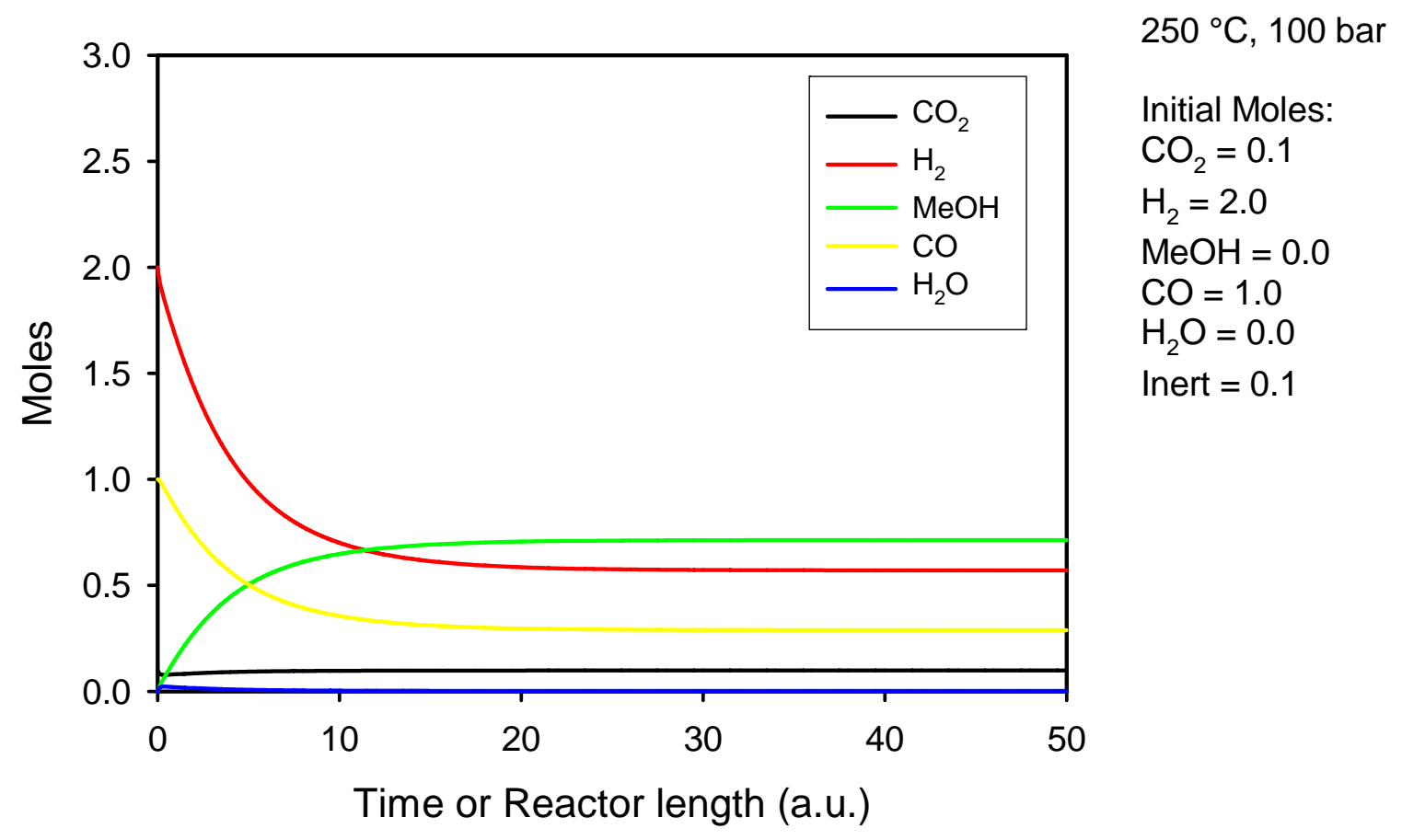

Figure B1. Calculated conversion of $\mathrm{CO}_{2}$-containing synthesis gas to methanol over $\mathrm{Cu} / \mathrm{ZnO} / \mathrm{Al}_{2} \mathrm{O}_{3}$ (Kubota Model). 


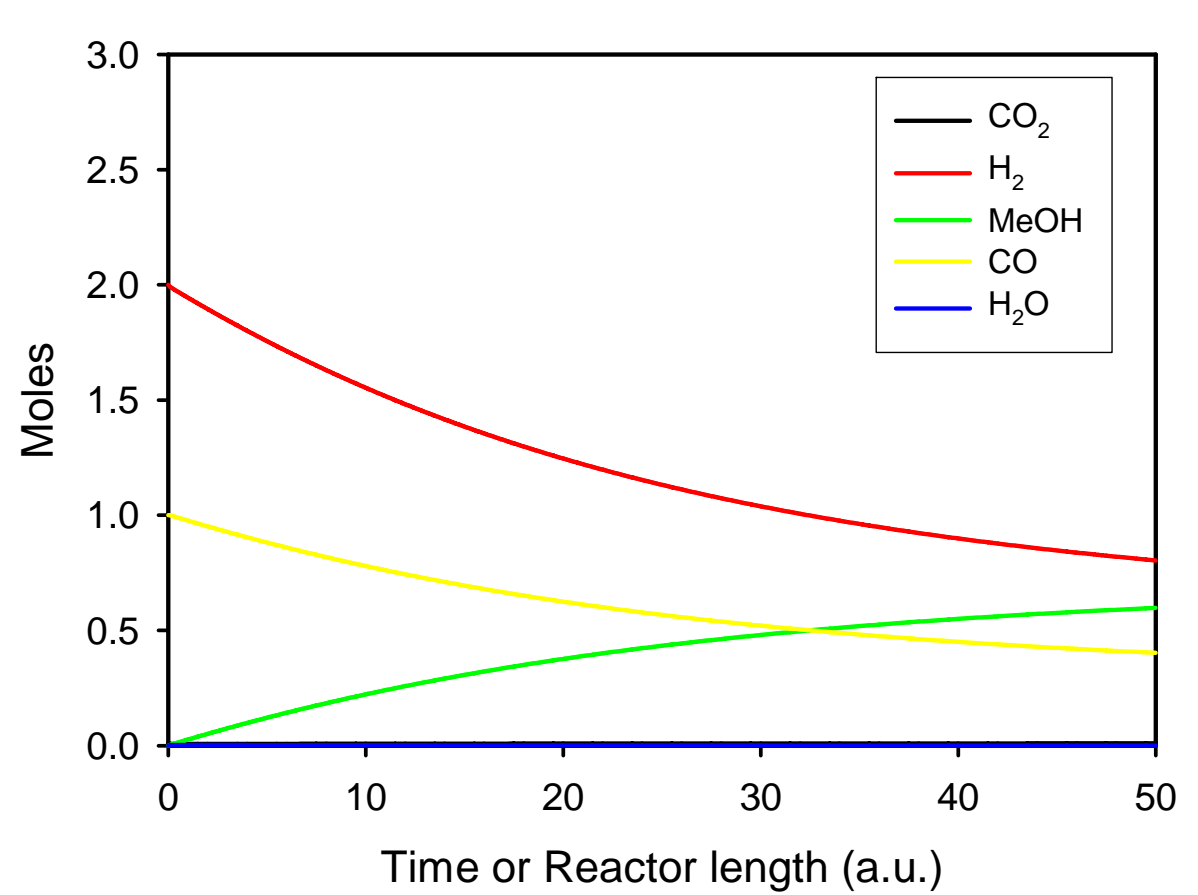

$250^{\circ} \mathrm{C}, 100$ bar

Initial Moles:

$\mathrm{CO}_{2}=0.01$

$\mathrm{H}_{2}=2.0$

$\mathrm{MeOH}=0.0$

$\mathrm{CO}=1.0$

$\mathrm{H}_{2} \mathrm{O}=0.0$

Inert $=0.19$

Figure B2. Calculated conversion of synthesis gas to methanol over $\mathrm{Cu} / \mathrm{ZnO} / \mathrm{Al}_{2} \mathrm{O}_{3}$. Syngas feed is dry and $\mathrm{CO}_{2}$ deficient (Kubota Model).

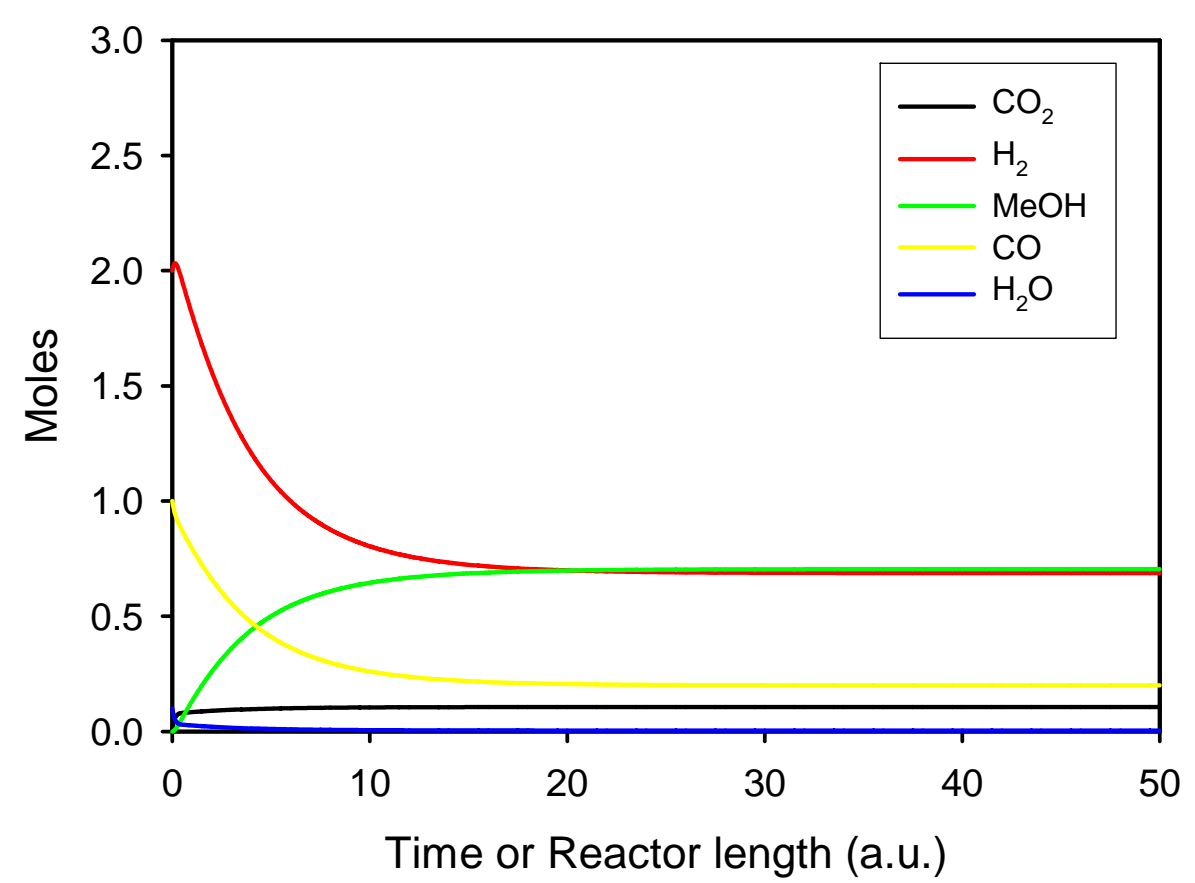

$250^{\circ} \mathrm{C}, 100$ bar

Initial Moles:

$\mathrm{CO}_{2}=0.01$

$\mathrm{H}_{2}=2.0$

$\mathrm{MeOH}=0.0$

$\mathrm{CO}=1.0$

$\mathrm{H}_{2} \mathrm{O}=0.1$

Inert $=0.09$

Figure B3. Calculated conversion of synthesis gas to methanol over $\mathrm{Cu} / \mathrm{ZnO} / \mathrm{Al}_{2} \mathrm{O}_{3}$. Syngas feed is $\mathrm{CO}_{2}$ deficient, but moist (Kubota Model). 


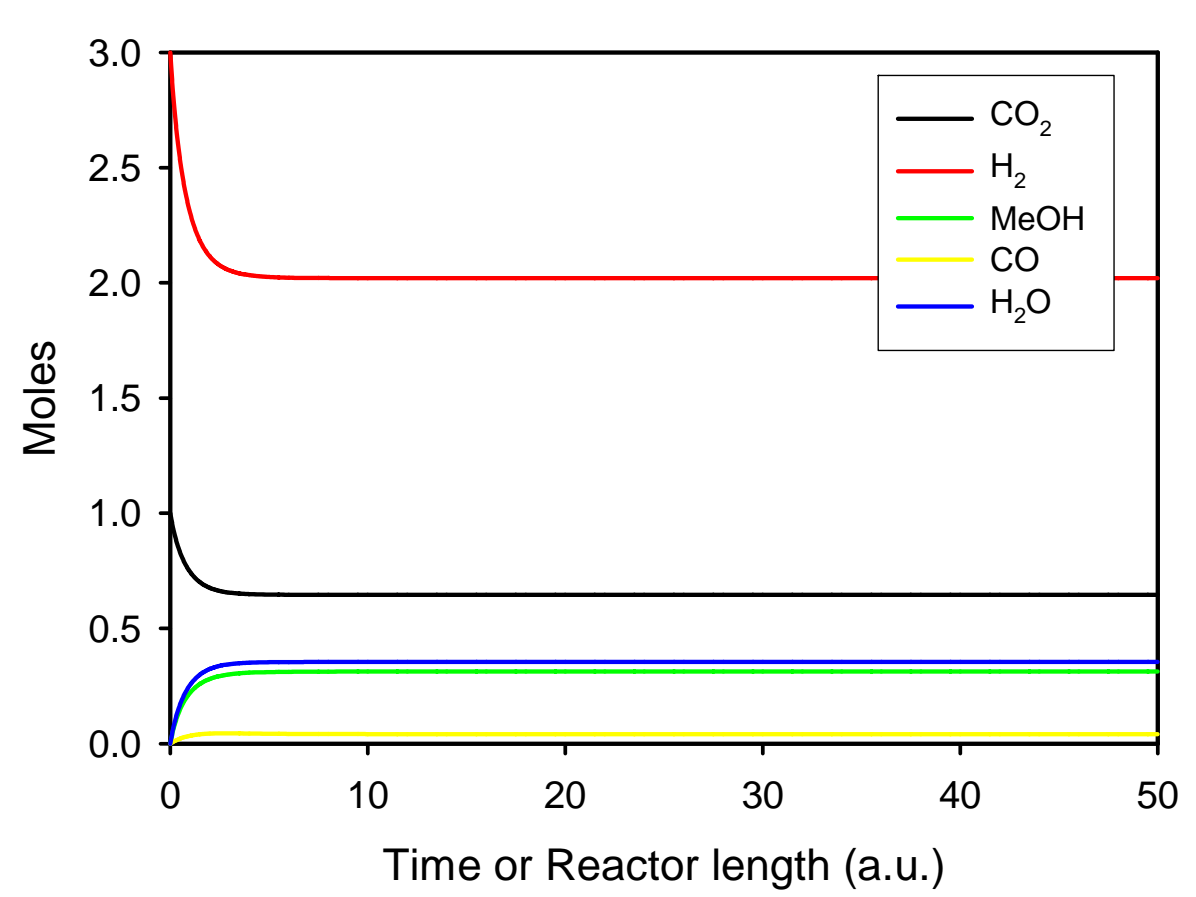

$250{ }^{\circ} \mathrm{C}, 100$ bar

Initial Moles:

$\mathrm{CO}_{2}=1.0$

$\mathrm{H}_{2}=3.0$

$\mathrm{MeOH}=0.0$

$\mathrm{CO}=0.0$

$\mathrm{H}_{2} \mathrm{O}=0.0$

Inert $=0.2$

Figure B4. Calculated conversion of dry 3:1 $\mathrm{H}_{2}: \mathrm{CO}_{2}$ mixture to methanol over $\mathrm{Cu} / \mathrm{ZnO} / \mathrm{Al}_{2} \mathrm{O}_{3}$ (Kubota Model).

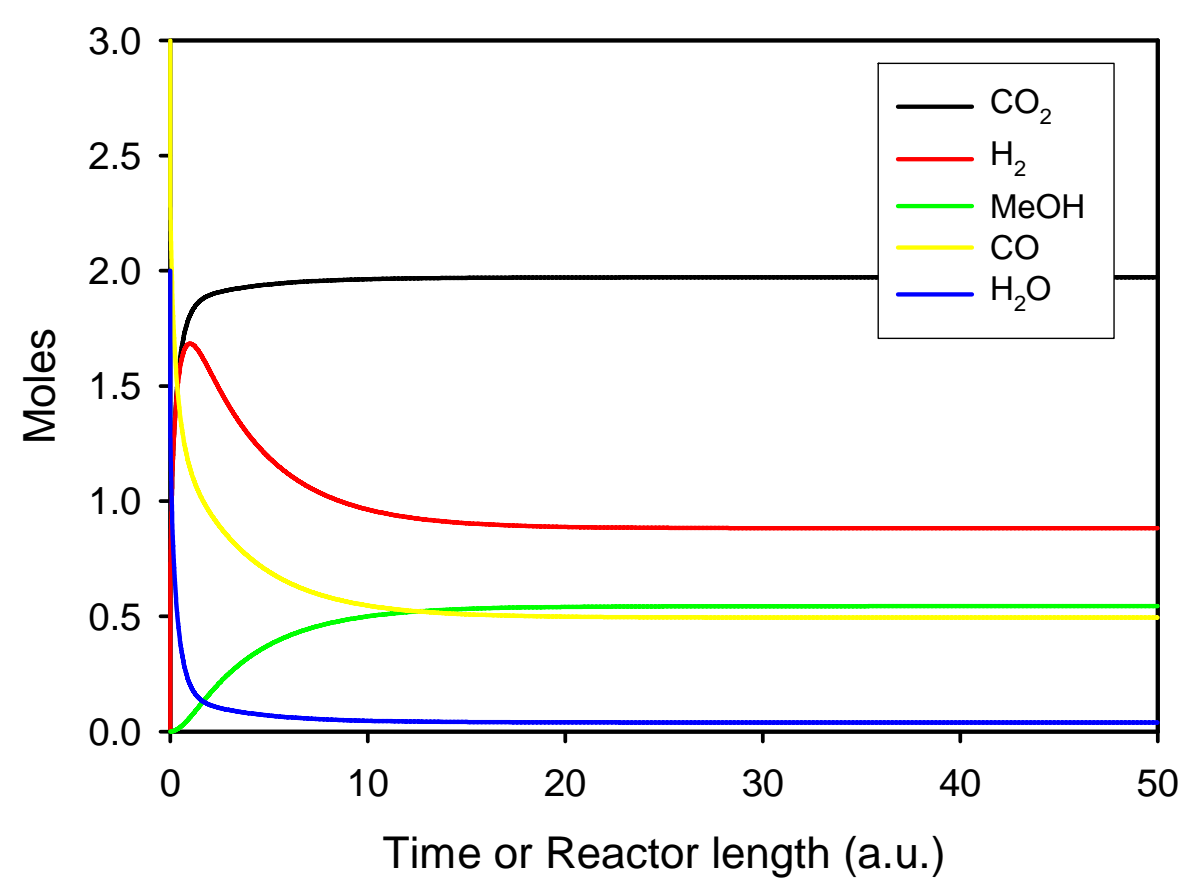

$250{ }^{\circ} \mathrm{C}, 100$ bar

Initial Moles:

$\mathrm{CO}_{2}=0.01$

$\mathrm{H}_{2}=0.01$

$\mathrm{MeOH}=0.0$

$\mathrm{CO}=3.0$

$\mathrm{H}_{2} \mathrm{O}=2.0$

Inert $=0.18$

Figure B5. Calculated conversion of 3:2 CO: $\mathrm{H}_{2} \mathrm{O}$ mixture to methanol over $\mathrm{Cu} / \mathrm{ZnO} / \mathrm{Al}_{2} \mathrm{O}_{3}$ (Kubota Model). 


\section{DISTRIBUTION:}

10 MS 1349 James Miller, 1815

1 MS 1349 Lindsey Evans, 1815

1 MS 1349 Eric Coker, 1815

1 MS 1349 Rick Kemp, 1815

1 MS 1349 Bill Hammetter, 1815

1 MS 0887 Justine Johannes 1810

1 MS 0887 Duane Dimos, 1800

1 MS 0734 Andrea Ambrosini, 6338

1 MS 0734 Ellen Stechel, 6338

1 MS 1127 Rich Diver, 6335

1 MS 1127 Nathan Siegel, 6337

1 MS 1110 Jeff Nelson, 6330

1 MS 0406 Fred Gelbard, 5713

1 MS 1415 Roland Stumpf, 1114

1 MS 0123 LDRD, Donna Chavez, 1011

1 MS 0899 Technical Library, 9536 (electronic copy) 


\section{Sandia National Laboratories}

